(5)

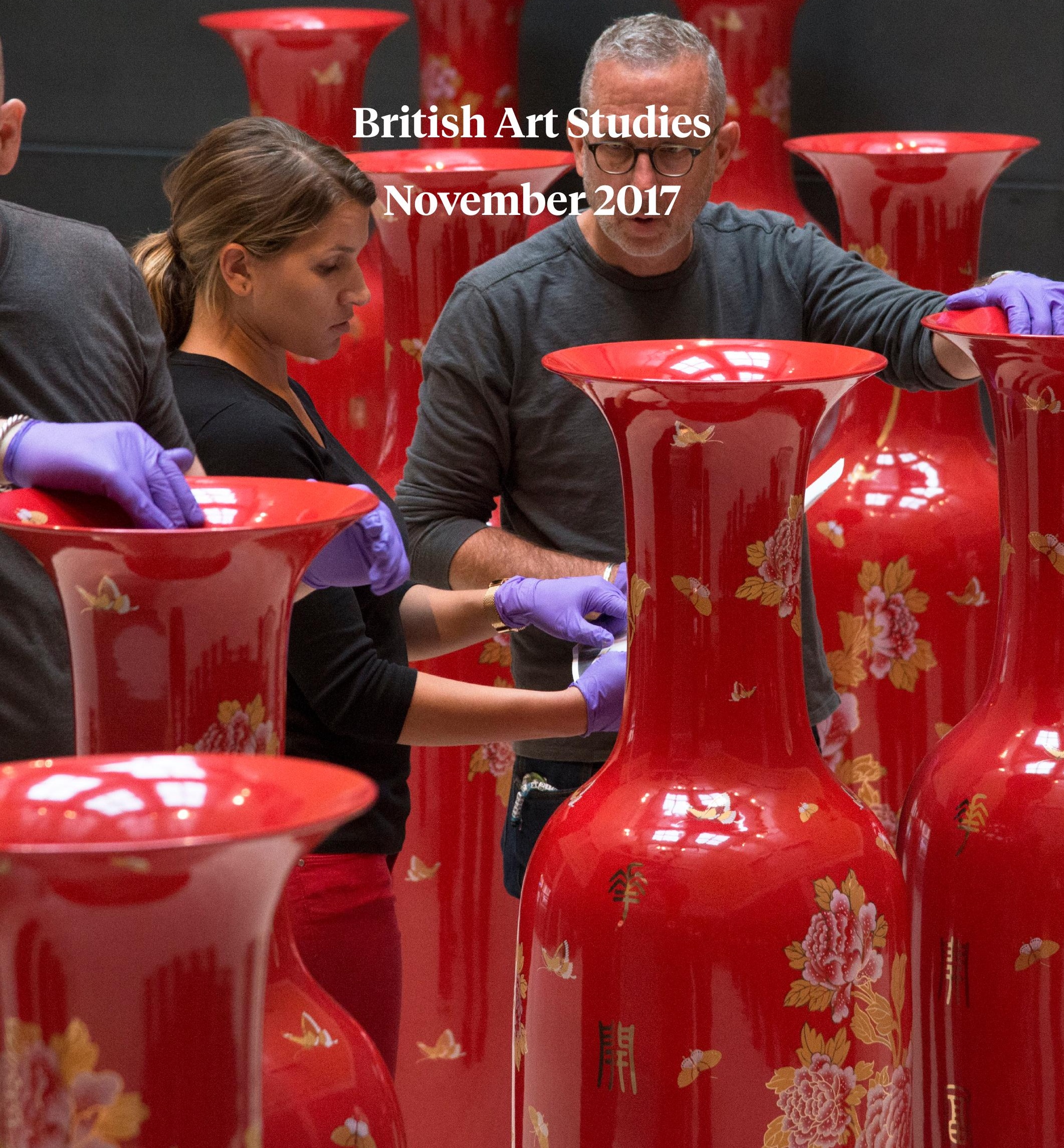


British Art Studies

Issue 7, published 30 November 2017

Cover image: Clare Twomey, Made in China, ceramic vessels, 2016. Installed the Yale Center for British Art, New Haven, 2017.. Digital image courtesy of Yale Center for British Art I Photo: Richard Caspole

PDF generated on 14 April 2022

Note: British Art Studies is a digital publication and intended to be experienced online and referenced digitally. PDFs are provided for ease of reading offline. Please do not reference the PDF in academic citations: we recommend the use of DOIs (digital object identifiers) provided within the online article. These unique alphanumeric strings identify content and provide a persistent link to a location on the internet. A DOI is guaranteed never to change, so you can use it to link permanently to electronic documents with confidence.

Published by:

Paul Mellon Centre

16 Bedford Square London, WC1B 3JA

https://www.paul-mellon-centre.ac.uk

In partnership with:

Yale Center for British Art 1080 Chapel Street

New Haven, Connecticut

https://britishart.yale.edu

ISSN: 2058-5462

DOI: 10.17658/issn.2058-5462

URL: https://www.britishartstudies.ac.uk

Editorial team: https://www.britishartstudies.ac.uk/about/editorial-team Advisory board: https://www.britishartstudies.ac.uk/about/advisory-board

Produced in the United Kingdom.

\section{Ajoint publication by}




\section{Contents}

A Photobook of the Shimmer:

Pearl Fisheries, Photography, and British Colonialism in South Asia, Natasha Eaton 


\title{
A Photobook of the Shimmer: \\ Pearl Fisheries, Photography, and British Colonialism in South Asia
}

\author{
Natasha Eaton
}

\section{Abstract}

This article examines Lionel Wendt's photographs of the Sri Lankan shoreline and its pearling economy during the British occupation in the 1930s and 1940s. It considers the light they shed on labour, as well as the tangled relationships between wealth and waste, in an environment where the detritus (cultch) generated by harvesting luxury pearls also formed the most common building materials. The ambivalences of Wendt's aesthetic are connected to the qualities of pearlescence and the shimmer, which themselves were freighted with both metaphorical meaning and technical possibility, for theorists of modernity like Walter Benjamin and early scientists of photography alike. Considering what was, and was not depicted in Wendt's photographs, the article describes the materiality of the coercive labour that existed in the Gulf of Manaar, as well as its connected imaginaries, both local and colonial.

\section{Authors}

Reader in the History of Art at University College London

\section{Acknowledgements}

Research for this essay was funded by fellowships from The Leverhulme Trust and the Paul Mellon Centre for Studies in British Art. For their intriguing ideas relating to pearls and Deleuze's take on the shaman, I would like to thank Renate Dohmen and Ibrahim Raheem. Much gratitude to Marcia Pointon for encouraging me to write about pearls and to Sugata Ray for his interest in "Liquescent Materiality". Alipio Correia de Franca Neto offered much inspiration regarding poetry-here in the spirit of Neruda. Earlier versions of this essay were presented at The Paul Mellon Centre for Studies in British Art, Vanderbilt University, Oxford University, and the University of Leiden. I would like to add special thanks to the Paul Mellon Centre and British Art Studies for their encouragement and guidance. Any errors are my own. 


\section{Cite as}

Natasha Eaton, "A Photobook of the Shimmer:

Pearl Fisheries, Photography, and British Colonialism in South Asia", British

Art Studies, Issue 7, https://dx.doi.org/10.17658/issn.2058-5462/issue-07/ neaton 


\title{
Photobook Aesthetics and Shadows Beyond "An Eye for the Tropics"
}

\author{
But an earthly stone Flashing here and there Changed into a dove \\ Changed into a bell Into immensity, into a piercing Wind; Into a \\ phosphorescent arrow, Into salt of the sky. ${ }^{1}$
}

Writing with the memory of his deceased friend Lionel Wendt (1900-1944) in mind, Neruda described silence "intensified into a stone" where "broken circles are closed". $\underline{2}$ The Sri Lanka-based photographer Lionel Wendt is now best known for his posthumously published "Photobook". $\underline{3}$ Wendt's photomontage has been most conventionally and variously comprehended through its pastiche of influences and motifs such as De Chirico's futurist arches, Magritte's "Ceci n'est pas un oeuf," Piero della Francesca's Brera Madonna, Georges Bataille's rumination on the story of the eye, and the recurrent vignette of a distant brig. ${ }^{4}$ (Fig. 1) Although he clearly held great admiration for those artistic circles he came into contact with in Europe, it seems a bit too summary merely to insert him within these narratives.

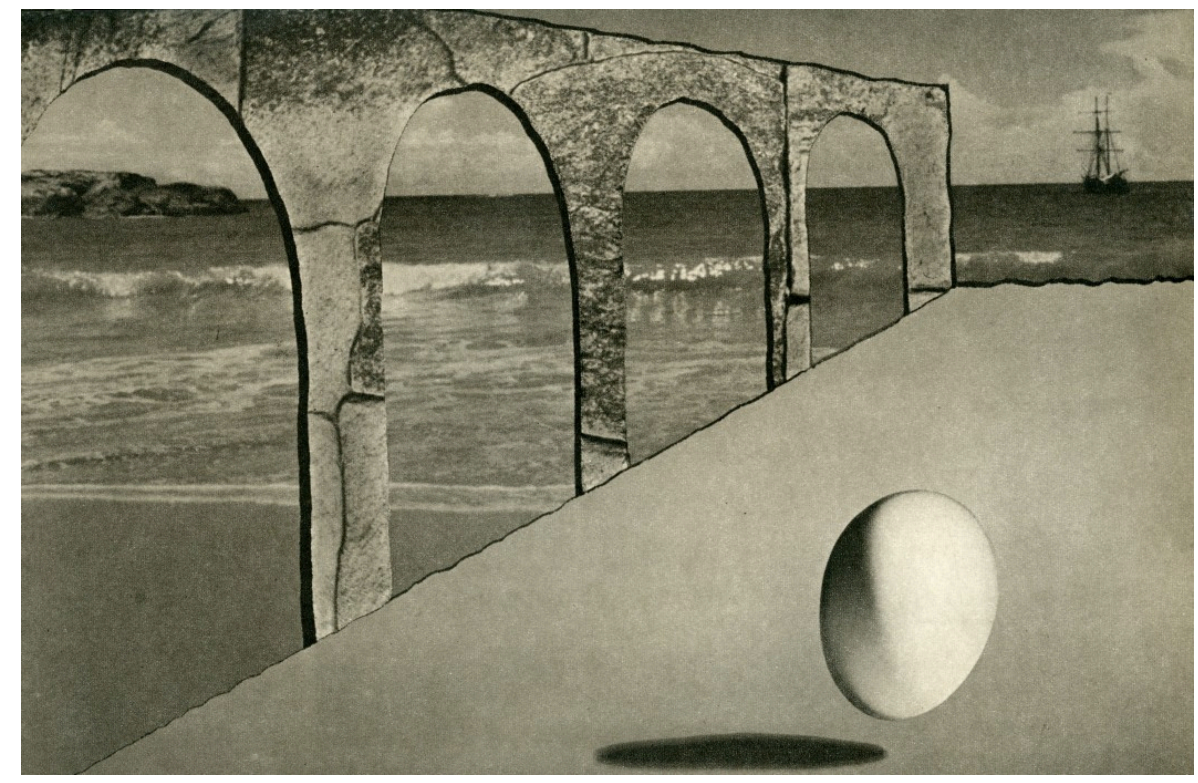

Figure 1.

Lionel Wendt, Gay Abandon, ca. 1940, photogravure, from Lionel Wendt's Ceylon (London, Lincolns-Prager Publishers Ltd, 1950). Digital image courtesy of Lincolns-Prager Publishers Ltd.

I would like to conjecture that there is another kind of more localized geopolitics at stake-one which is sometimes a faint or spectral presence in his images. These images are only one aspect of what I propose is a kind of virtual photobook or distinctly colonial Ceylonese genre of photography. 
Today this photography is much desired: the late nineteenth-century firm Plâté \& co., based now in downtown Colombo, has (given the obscure subject matter) quite a substantial collection of glass slides to do with pearling by many photographers (though none of them by Wendt), to which I shall return. Wendt is otherwise very much present in the city's reverence for Group 43, a modern art movement formed in Colombo in 1943, and the Photographic Society of Ceylon. He's also tied into a network of private collectors, who like to brandish him as the great artist of the city, in spite of his obvious colonial position, and suspect cosmopolitanism associated with his time in Western Europe. As part of my fieldwork this spring, I devised the notion of an essay as photobook. Wendt's hundreds of photographs are a miscellaneous, sprawling constellation of collections scattered across many countries.

I want to anchor his work within the environs of Sri Lanka, that is, the photographic practices, commercial and otherwise, present there during his lifetime, so as to flesh out a mid-twentieth-century aesthetic not much studied by scholars. I take photobook to be an expanded term, as a kind of collecting perhaps not dissimilar to how one might approach assembling or interpreting an album. "Photobook" can and does encompass postcards, official publications, and mestijzo painting, to exist as a veritable ragbag. For instance, Skeen \& co's azure/argent moonlit beach sold as a postcard might pertain to Wendt's artistic attempts to capture the shadows typical of shoreline aesthetics (Fig. 2). But Wendt's manner of seeing goes beyond "an eye for the tropics" where, as Derek Walcott puts it, a scene needs to have "proper palm trees". ${ }^{5}$ Rather, there is at times in Wendt's extensive oeuvre a conflation of shoreline shadow with the pain of labouring bodies that is difficult to account for aesthetically (Fig. 3 and Fig. 4). The frequency of crouching figures' backs, presented close-up, more than counters Wendt's current reputation as a champion of the erotic male body. Wendt's contemporary, the colonial fisheries' official James Hornell (who was employed in Colombo from 1900 to 1906), practised a kind of photography that sought out the blurred sepia-toned movements of multiple bodies in action, and continued to publish on colonial maritime economy in the decades following. Wendt's use of photogravure, by contrast, and precise study of the male body, might be seen as attempt to both escape from and celebrate labour. 


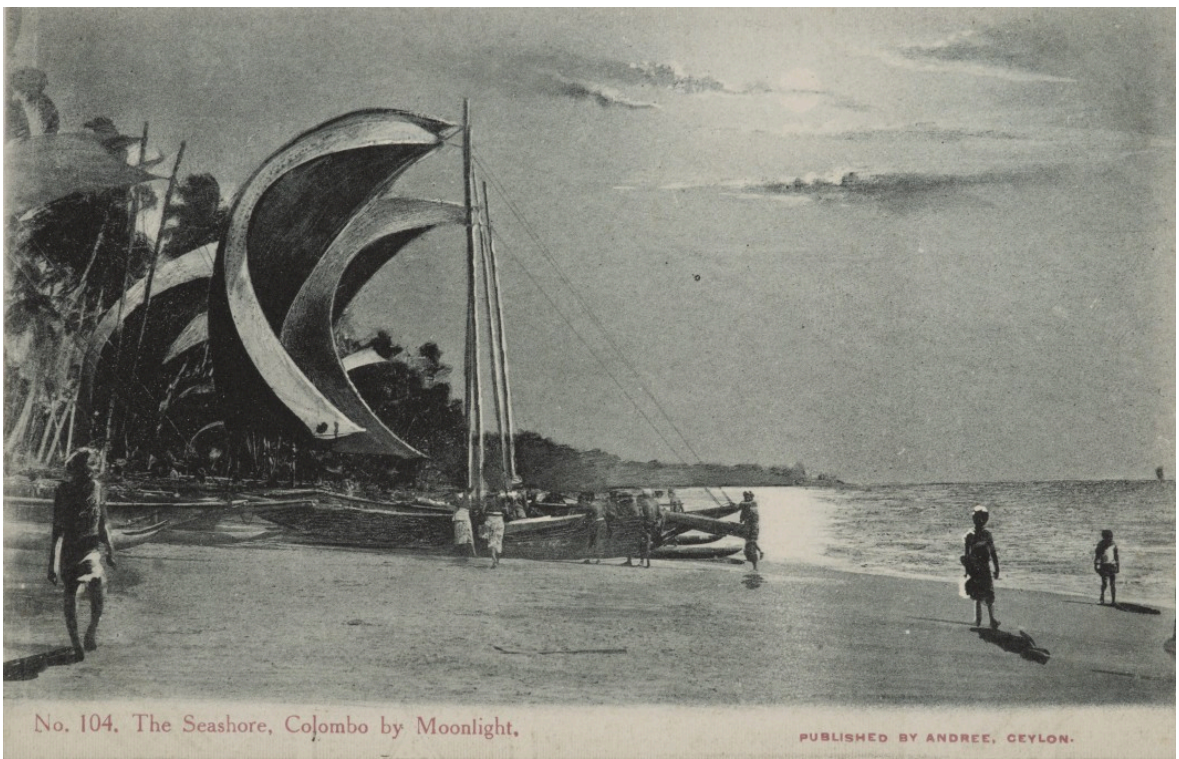

\section{Figure 2.}

Andrée Photographic Studio, Colombo, Postcard No.104, The Seashore, Colombo by Moonlight, ca. 1930. Collection Alkazi Foundation for the Arts, Delhi. Digital image courtesy of Alkazi Foundation for the Arts, Delhi.

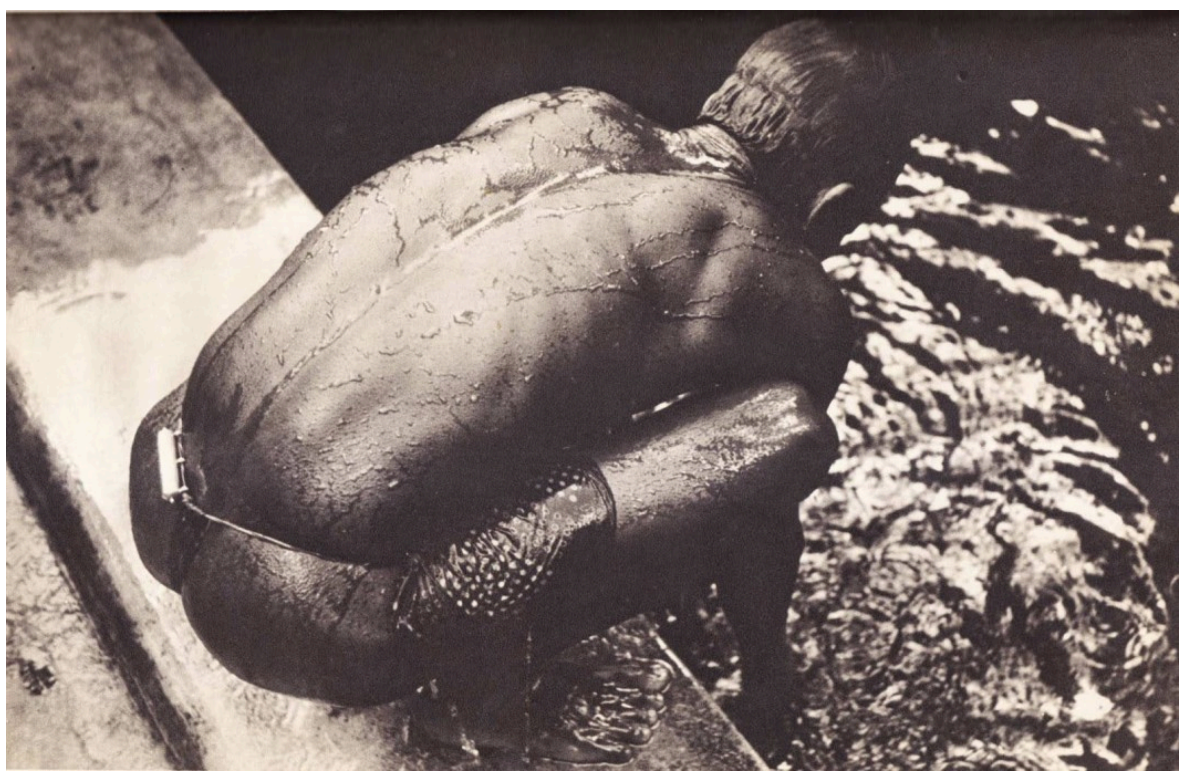

\section{Figure 3.}

Lionel Wendt, Untitled Study, ca. 1940s, gelatin silver print on paper. Digital image courtesy of Lionel Wendt Foundation for the Arts, Colombo, Sri Lanka. 


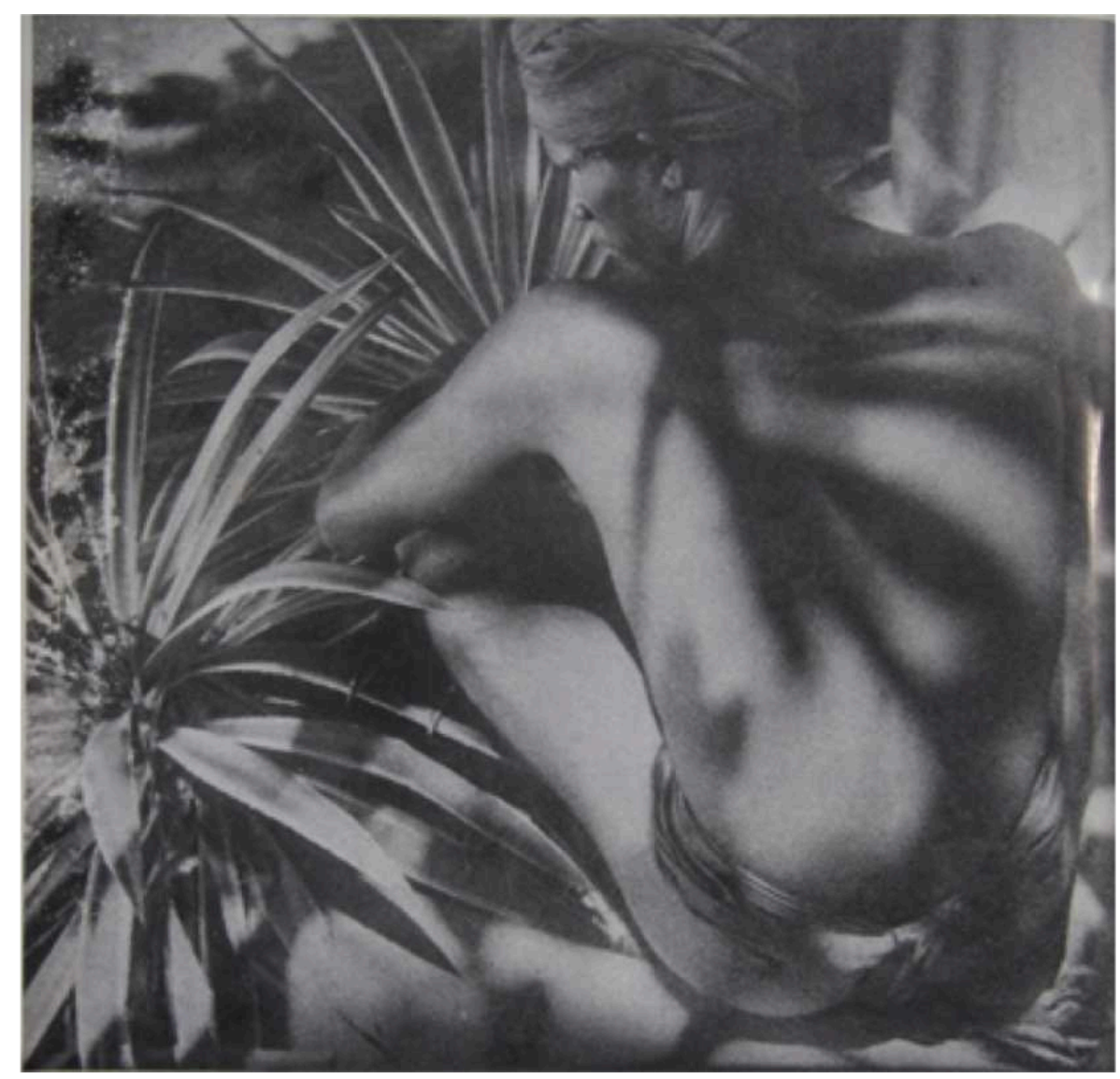

Figure 4.

Lionel Wendt, Untitled Study, ca. 1940s, gelatin silver print on paper. Digital image courtesy of Lionel Wendt Foundation for the Arts, Colombo, Sri Lanka.

To think about the photobook in this way also allows us to ruminate on photography qua analogy and the magical. As is well known, Walter Benjamin being inspired by photography and mechanical reproduction made aura formative to his theories on the entanglement of aesthetics and politics. What interests me here is how his fascination with photography, labour, and magic have had such a formative role in studies of colonialism. Both Christopher Pinney and Michael Taussig make the case for a kind of Benjaminesque legacy-one where perceptions of colonial realities are infused with hashish, shamanism, and the fuzziness of the holograph. $\underline{6}$ In their work, Pinney and Taussig conceptualize photography as both the palimpsest and the interval. There is something of the proto-cinematic about the photographic when read in this anthropological light. What I mean by this is that there is a strong sense of movement, depth, and interruption that can be read in relation to Wendt's seemingly often oblique engagement with labour. 
The same quality of movement, tied to improbable or magical transformations, is seen in both Neruda's poem and Gay Abandon, which each metamorphose a stone into the weightless and possibly the ephemeral. Neruda's "earthly stone" becomes a dove, a bell, into "immensity". The abstract stone in Wendt's photograph is similarly in suspension, perhaps caught in a thick air with a shadow cast. For the photographer and the poet, a "stone" and its play with light could encapsulate qualities of "phosphorescence" and illumination, and how this might pertain to the materiality of pearlescence. Through the lens of colonial photography, this sense of "stone" can be projected onto a divers' labour, the pearl, their shells, and transformations between detritus and value. In this sense, I propose that in various ways the pearl economy was critical to forging modern photographic practices and notions of memory. Here I'm less interested in viewing pearls as rarities than in analysing pearl shells' status as both the waste and the currency of British colonialism. ${ }^{7}$ Certainly in the Gulf of Manaar it would seem that the need for lime (chunam) made from oyster shells (essential to building/architecture) long pre-dated the market for seawater pearls.

\section{Echoate Modernity and the Archaic}

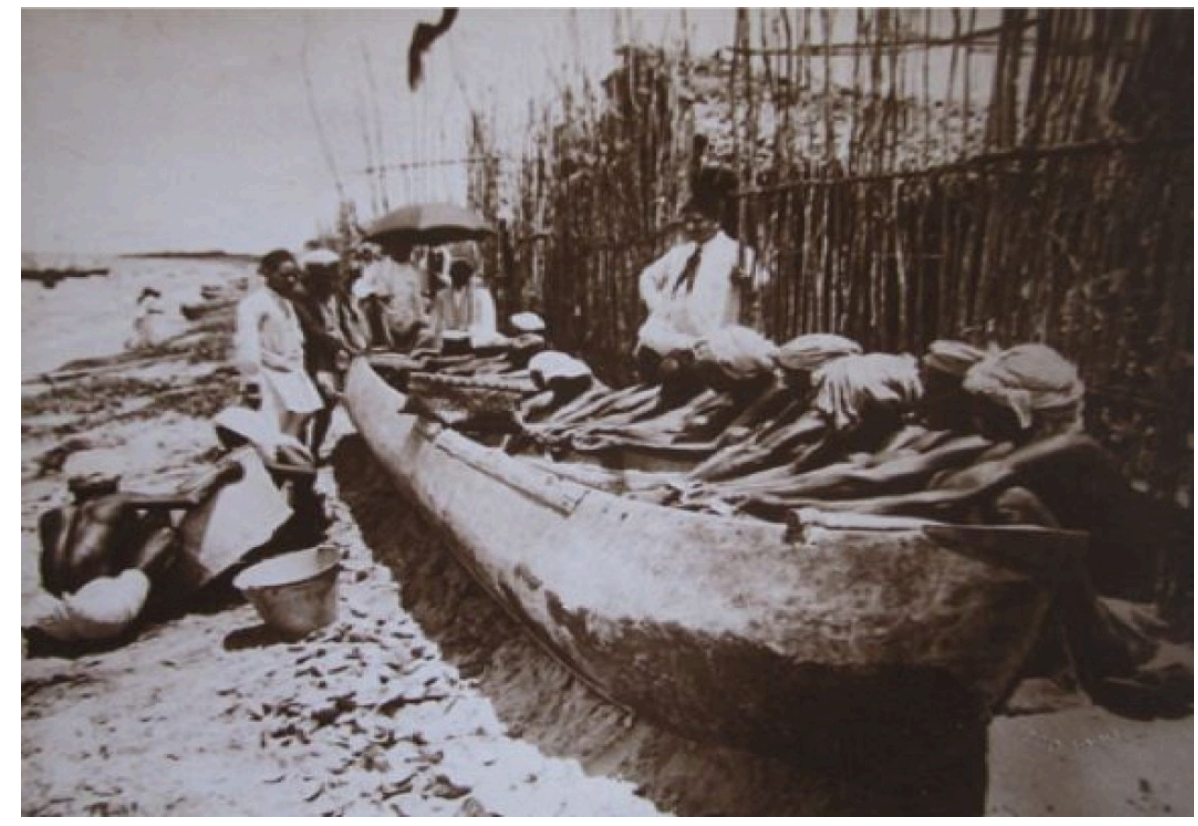

Figure 5.

Unknown creator, Pearl divers waiting to embark on a voyage of pearl fishing, ca. 1920s. Collection Natasha Eaton. Digital image courtesy of Plate \& co., Colombo, Sri Lanka.

In the sepia glare of the early sun, two boats' worth of divers bare their hands up to, for, and against the world (Fig. 5). The janissary and his team stand a little at a distance seemingly engaged or not; it's difficult to tell, 
given the scrubby quality of the blown up reproduction and its veering chiaroscuro. Waiting for the two boats from which the government wants them to dive, the divers have now been made to chuck shells. For the outfit, a pearl or two picked from shell flesh under lazy scrutiny will not go awry. Bleached in, stained by the light, their limbs outstretched almost beyond measure, the divers offer a glimpse of a kind of economy of pearling not otherwise recorded in or by photography. It's a kind of pearling of the anticommons: there is a coercive as well as performative aspect to both the activity and the image. A dugout canoe dragged up to the kotthu (the official shelling enclosure) just to bestow perspective; the shoreline as a dumping ground for shells and the shoreline made to cohere as the shelling commons in toto. The image is titled "Pearl Divers Waiting to Embark on a Voyage of Pearl Fishery c.1920's [sic.], Marichchikadi", intimating that even waiting turns into coerced labour, which otherwise would seem to have no surplus value. $\underline{8}$

More theoretically, there have been two principal ways of thinking about the relationship between the modern self and the shell: the shell as channelling sound and memory, and as a metaphor for personal psychic terrains. For Walter Benjamin, seashell sounds take two forms-a mythical model that has seashells as conduits for voices from a communal past and a materialist model whereby seashells resonate as the chambers of individual, located experience: "what Benjamin hears in the conch is the primordial murmurings of the universe, but in the form of their smallest acoustical singularities." $\underline{9}$ It brings to mind his Berlin childhood: "like a mollusk in its shell, I had my abode in the nineteenth century, which now lies hollow before me like an empty shell." $\underline{10}$ The shell is also the space for distorted self-reflection. In Germaine Dulac and Antonin Artaud's proto-surrealist film, The Seashell and the Clergyman (1928), the deluded priest drinks from and stares at his reflection in a giant shell only to see how the shell metamorphoses into a mirror and throws into space what might be one way of exploring the unconscious in modernity. ${ }^{11}$ The process of thinking and writing may itself be understood as "oyster-like. We inhabit strange folds, closures, openings. We dive into the oyster's chaotic insides, the pool of confusing liquid that its shell contains like diverse that plunge in head first in search of pearls." 12

During the epoch of British colonization of the ocean and the shoreline of the Gulf of Manaar, the figure of the diver came to be increasingly romanticized. The world of the underwater was played with by Jules Verne, Georges Bizet, and Jules Michelet, and materialized by the eerie phosphorescent light of the aquarium and the emergence of narratives of submarine adventures and underwater photography. $\frac{13}{}$ But the "birth of the aquarium" and "tragedy of the commons" also signalled the rise of regimes, which viewed the sea as a giant aquarium that needed to be enclosed. $\frac{14}{}$ Although there is fascinating 
literature on this position, there are also alternatives where the multi-layered and more uncertain notions of temporality, space, and rights must be accounted for. More productively, administrative materials taken from the Manaar colonial archive can be entangled with photographic practices (and their absence) to suggest unusual and sometimes elliptical alignments of art and politics. For instance, in Wendt's "Gay Abandon" (Fig. 1), the anachronistic Dutch brig approaching the shoreline and the shape of the stone akin to one type of pearl valued in the Sri Lankan jewel market, can also suggest a complex economy of pearl trading which shaped the architecture and the shoreline of the Gulf of Manaar. Stone, I insist in this essay, is not necessarily pearl but also "culch" (broken shells, grit, and rocks in which oyster beds form) or the diver's 15 to 20lb "Christ Stone", the function of which is unknown beyond its importance to the divers, many of whom were Christians. It also resonates with the world of sharks, shamans, and the diver. $\underline{15}$

To mark these overlaps between art and politics, Wendt's photographic montage works as a point of entry into the colonial economy of the pearl and the pearl shell. This mode of inquiry is not intended as a comprehensive study of Wendt's work but rather his scattered photographs (posthumously gathered and published, then recently republished, and now rumoured to be the subject of an upcoming Tate exhibition) serve as means of approaching the status of photography in relation to pearls as materials, as trade, as magical substance, and as waste. $\frac{16}{}$ Wendt's family were wealthy burghers, who made money from luxury trades and jurisprudence-a kind of economic jurisprudence built on the backs of pearl divers.

Relatively recently, Taussig has turned self-reflexively to his own photographs, drawings, and fieldwork notebooks, all of which point to "another order of reality altogether"; a "wild miscellany". 17 Photographs act as devices for delving into economic exploitation and all of its strange "beauty". $\underline{18}$ Photographs also find a mnemonic parallel in Taussig's excursus on Simryn Gill's Pearls (1989-) (Fig. 6). Informed by the rhetoric of bibliomancy, Gill either mines second-hand bookstores and flea markets for works by Fanon, Benjamin, and many provocative or playful writers (Borges et al.), or she cuts out from books sent as gifts. In both cases, she carefully destroys the text to fashion what she believes to be prescient constellations of words, which she carefully folds and folds over and over, to gesture towards the layers of both a pearl and the act of reading. She sent Taussig one of her pearl necklaces from Australia, each pearl being made up of a line cut from Walter Benjamin's essays "Unpacking my Library", "Letter to Gerhom Scholem on Kafka", and "Berlin Childhood". The incision of her knife into the text steals and transforms the book's organs, so that the content of the book is no longer accessible but is still present in pearl form. Asked to 
write on Gill's paper pearls, Taussig ruminates on the importance of photography to her practice. So fragile, perhaps such pearls are untouchable; their viscerality has to operate through the photographic image.

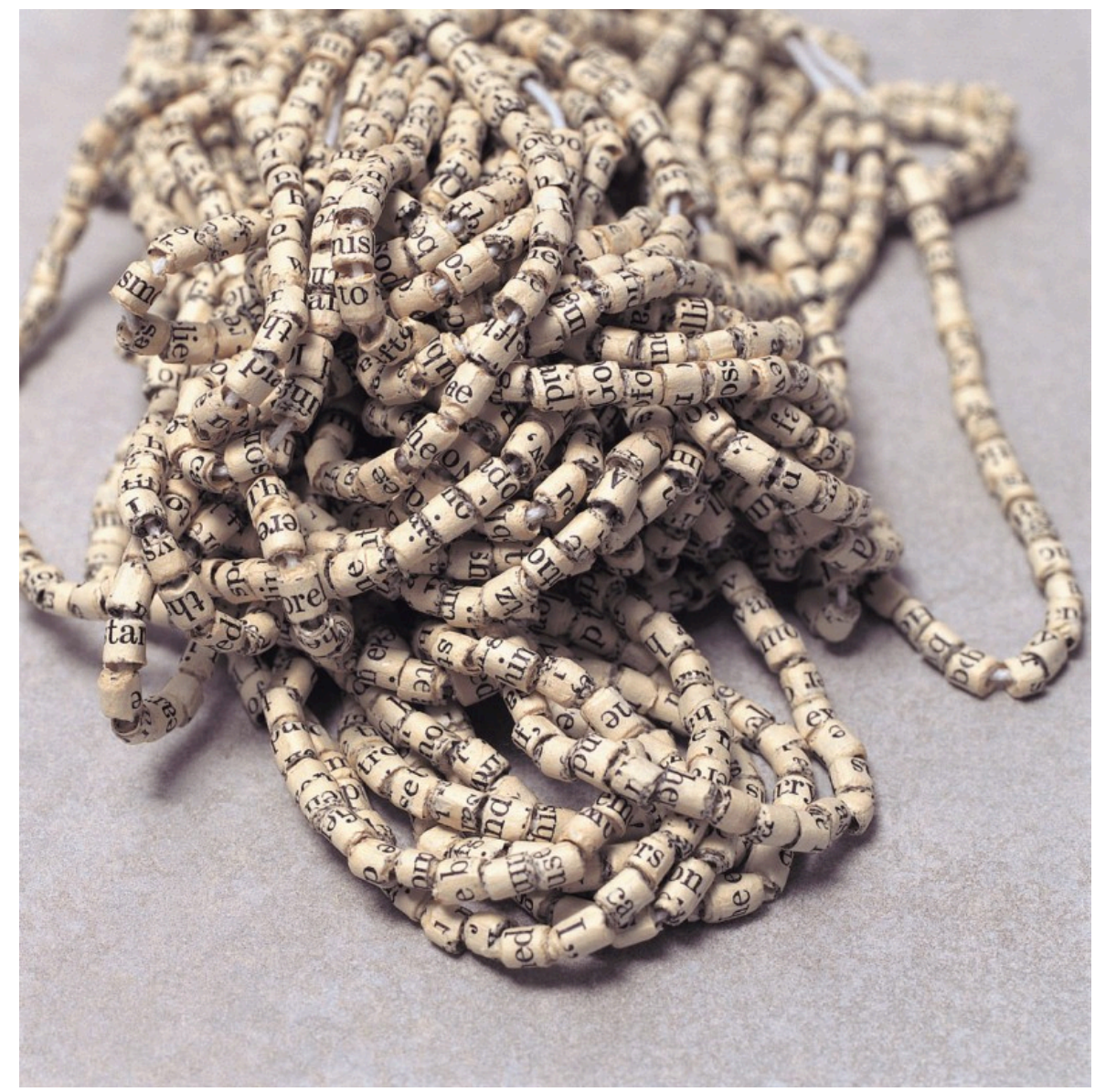

\section{Figure 6.}

Simryn Gill, Pearls, Joseph Conrad 'Heart of Darkness' in Three Stories: Youth, Heart of Darkness, The End of the Tether, (London, J.M. Dent and Sons Ltd., 1948), 2006. From Gill's ongoing Pearls series of paper necklaces, 1999 onwards. Private Collection, London. Digital image courtesy of Simryn Gill.

Sometimes worn by friends and strangers in the images, the pearl necklaces are of course criticisms of those worn by society women and maharajahs as photographed by the likes of Cecil Beaton. Wendt's engagement with the economy of the pearl is more difficult to pin down. Unlike the photography of James Hornell-the British official who I discuss below, best known for his extensive investigation of the Manaar fisheries-Wendt's poetic interventions are quiet, uncrowded, meditative. Neither is he is the participant observer as exemplified by his near contemporary Malinowski's study of resting pearl divers on the Trobriand shorelines. 
Perhaps intended as a critique of the kind of administrative photography associated with nacreous trafficking, they allude to a vanishing world of trading, melancholia, and nostalgia. This nostalgia would come to haunt Neruda's verse. In their works, neither Wendt nor Neruda employed a coherent narrative: both their verse and photographs (as precursors of Gill's paper necklaces) can be read as singular "pearls of wisdom" loosely strung together. Wendt and Neruda toured north-west Sri Lanka together during the 1930 s and 1940s. For thousands of years, the Gulf of Manaar or Salubham-The Sea of Grain - constituted the world's most important source of oyster shell, chank shell, lime, and pearls. The major South Indian ruler. Muhammad Ali, Nawab of the Carnatic (r. 1749-1795), refused to allow any pearl fisheries during the Dutch VOC's occupation of Ceylon. After his death and British conquest of Ceylon the following year, the English East India Company attempted relentlessly to extract pearls from the Gulf of Manaar as an important new resource aimed at expanding markets for luxury goods in Russia and Europe. $\underline{19}$

Although there has been admirable scholarship on the coming of a machinedriven modernity and its "market imaginary" in late nineteenth-early twentieth-century Sri Lanka, what must also be accounted for is the persistence of the archaic and its tactical intervention in the formation of a fraught colonial modernity. $\stackrel{20}{2}$ The archaic is the world of the impoverished diver, who worked naked without the right to a diving suit, nose clip, or his own diving stone, forced to dive for up to twelve hours at a time with little reward and limited opportunity to sell his oysters at the daily sunset shore auction. ${ }^{21}$ It is also the world of the male or female itinerant shark shaman and their complicit "foe"-white colonialists and itinerant witches.

\section{Photography as Pearlescent}

In Strange Decor (Fig. 7), the seemingly random placement of a 1941 issue of Russia Today, lying on the quayside and showing its headline "Shaw on Stalin", the spectral presence of an eighteenth-century brig, and the cut-off telegraph station pole opens up a world of maritime telegraphy. The cultural theorist John Frow's insights on thingness hones in on the agency of a stone, a camera, and objects in a scene where human presence is everywhere implied yet not rendered. Such metamorphoses can be said to allegorise "a world in which a commercial trader is also a telegraph pole, and the telegraph pole takes on the human capacity to listen to the messages that pass through it [. . .]. The fusion is never complete." $\underline{22}$ Whilst Frow's is a suitably messy world of things, perhaps there is also room in his account for subaltern notions of magic. The broken-down telegraph station, deemed not worthy of being featured whole within the image, and the brig-as-ghost ship, speak to an economy already passed. Shark Charmers had once harnessed 
the telegraph wire to their huts as magical channels. Wendt's Adventure in Space (Fig. 8), reverses itself laterally twice. Offset by a brooding horizon, a man with an umbrella wonders the silverine shoreline alone. Possibly a Shark Shaman chanting mantras or praying until the pearling boats return, he might-unbeknown to us-be communicating with his two fellow shamans, that is, that isolated shaman regarding an Argentine fish talisman in his beach hut; the other working with the divers twenty miles out at sea . . .

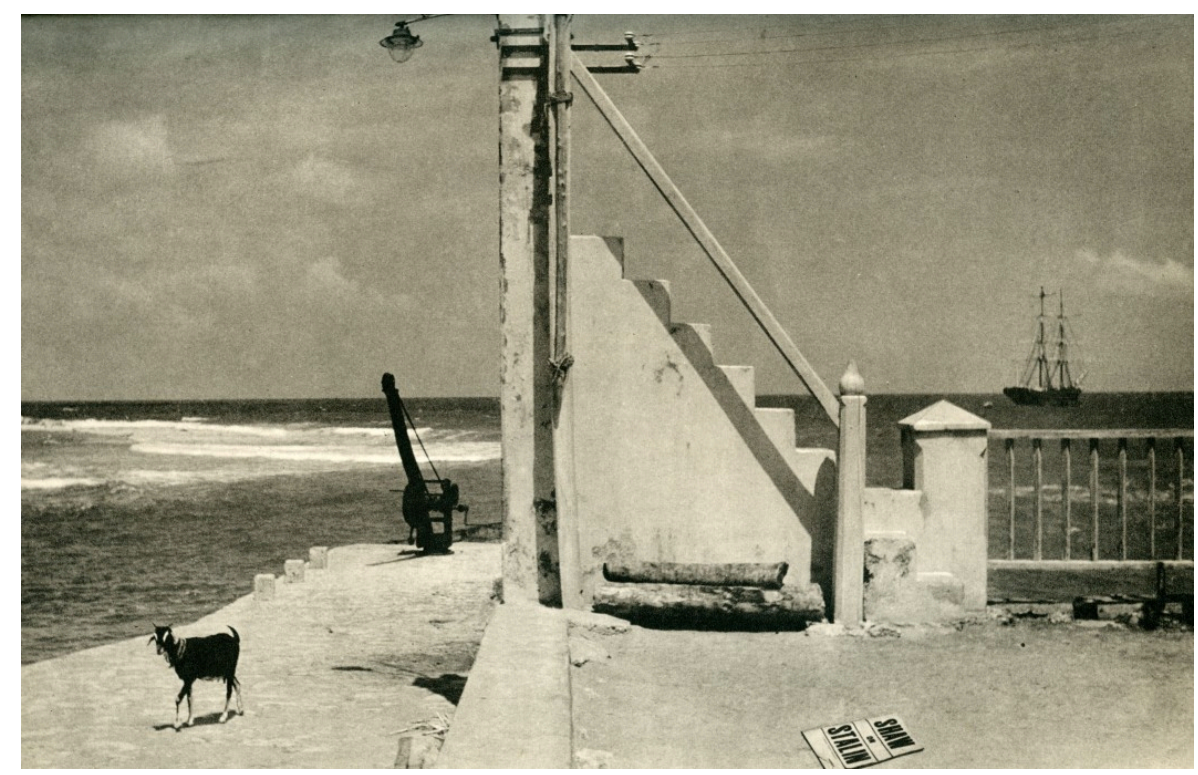

Figure 7.

Lionel Wendt, Strange Décor, 1933-34, photogravure, from Lionel Wendt's Ceylon (London, Lincolns-Prager Publishers Ltd, 1950). Digital image courtesy of Lincolns-Prager Publishers Ltd. 


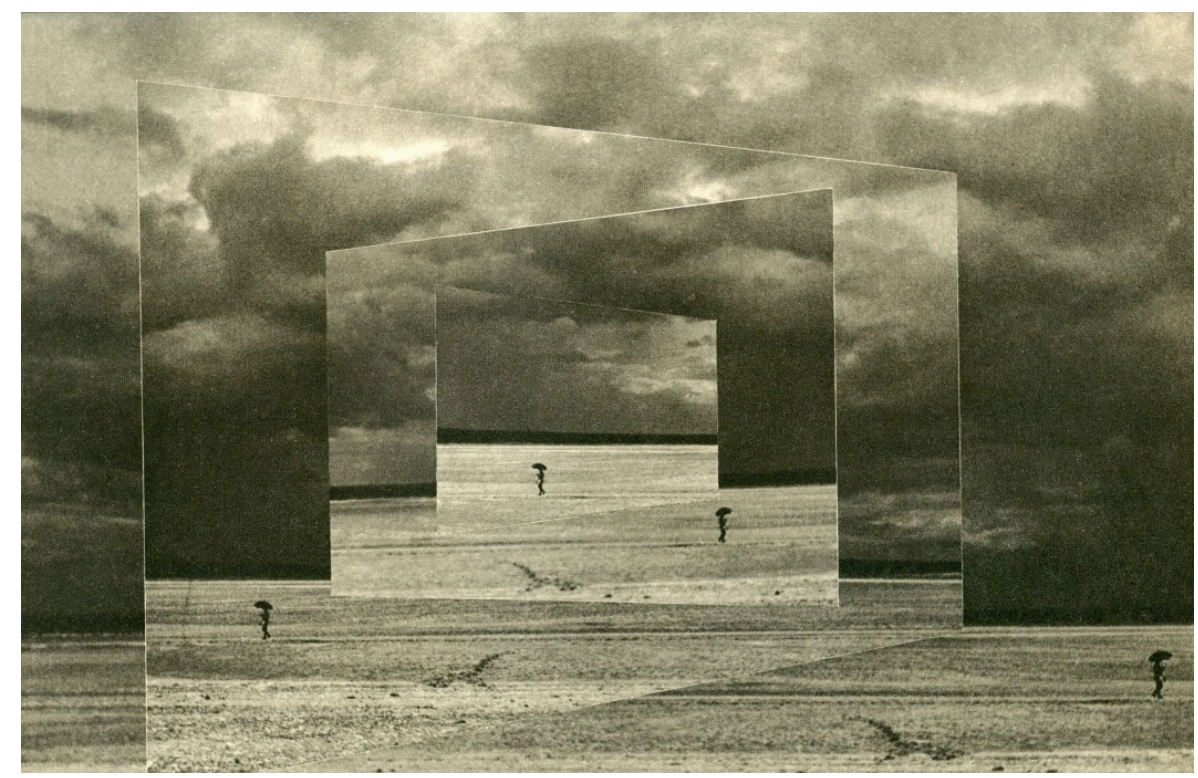

Figure 8.

Lionel Wendt, Adventures in Space, ca. 1930s-1940s, photogravure, from Lionel Wendt's Ceylon (London, Lincolns-Prager Publishers Ltd, 1950).

Digital image courtesy of Lincolns-Prager Publishers Ltd.

Pearls and pearl diving are also at the heart of the mythical formation of fieldwork-based anthropology and the parallel evolution of photography and its prehistories. $\frac{23}{}$ Perhaps photography from the outset (even in its predecessors) was to be at least partially grounded or framed by pearls and pearl shells. Frequently presented and kept safe in mother-of-pearl inlaid leather cases, it can be conjectured that nineteenth-century photographs are like pearls protected by a suitably shell-like lining. But there's more to it than that.

The inventor of the kaleidoscope was physicist, mathematician, and astronomer Sir David Brewster, who is most famous for his discovery of the photoelastic effect-a procedure which helped to bring into being optical mineralogy. His work was also important for later experiments to do with the photographic plate. Brewster fixed a piece of mother-of-pearl to an instrument for measuring angles with a "cement" of resin and beeswax. When removing the piece of mother-of-pearl from the cement in a hard state, using a knife to prise open the compound, Brewster found that "the plate of mother of pearl had left a clean impression of its own surface, and had actually given the cement the property of exhibiting its peculiar colours." 24 What intrigued Brewster was that the colours and the light of mother-of-pearl were not of an innate chemical nature; rather, they resided on its surface. When he examined this, he perceived a grooved exterior, "closely resembling the delicate texture of the skin at the tip of an infant's finger, or the minute corrugations often observable on surfaces which are covered with 
oil paint or varnish." $\underline{25}$ This impression of pearlescence could also be seen on the wax; these slight "mirrors" or material(ist) rainbows have certain grooves which break up a beam of light that falls upon the plates of shell:

each of which is reflected to the eye from the bottom and sides of the little grooves, and assumes a particular colour according to the angle at which it is reflected, the cause of iridescence was placed beyond all doubt. 26

This discovery triggered a mimetic/technological approximation of pearlescence. Several of Brewster's later experiments sought out "this singularly beautiful appearance", this particular combination of rainbow and iridescence through what he perceived to be the filmic quality of light. $\frac{27}{\mathrm{He}}$ believed that pearlescence could be transferred through the mediums of either gum Arabic or balsam of Tolu (South American resin tapped from the living trunks of Myroxylon toluiferum). Pressed between two plates of mother-of-pearl, a thin, iridescent film would be elicited. The effect of pearlescence could also be communicated by hammering mother-of-pearl onto a clean surface of lead or to a compound of mercury and bismuth. To dissect iridescence was to search for grooves. Sometimes there could be perceived 2,000 grooves per inch square within a certain pearlescent imprint. Often there were so many grooves that they were incalculable. But "the light will remain even when the mother of pearl is ground up." 28

Taken as the mnemonics of light, pearlescence would assume a critical agency in the formation of British currency. Mr John Barton (1771-1834) of the British Royal Mint took mother-of-pearl to be a model for British coinage: the number of grooves should somehow be equivalent. He devised an engine, which sought to approximate the number of grooves perceived by Brewster to be present on the inside of a shell. $\underline{29}$ :

Such surfaces, when viewed on a cloudy day present but few appearances of colour; but when the light of the sun or of gas falls upon them an extremely brilliant display of colours is the result:-every gradation of tint is exhibited, and a change is produced by every motion either of the object or the source of illumination. $\underline{30}$

Perhaps mother-of-pearl could itself become coinage or become akin to (perhaps even a prototype for) certain forms of photography. Barton, following Brewster, experimented with aquafortis, nitric acid, and "the 
cutting energies of the lapidary" in order to separate layers of mother-ofpearl. Through these experiments, scaly, transparent laminated structures could be made into impressions. These impressions could supplement tortoiseshell or veneers from certain woods, to be the mirrors of materials. Impressions of mother-of-pearl could, with turpentine varnish, be drawn onto films or plates. Then the shell is repeatedly brushed with strong, nitrous acid; those parts not varnished are eaten away. The varnish is then washed off with oil of turpentine. It is possible to cut several films of shell together. They are then soaked in warm water so as to prize them apart from one another.

In the early days of the daguerreotype, photographers intended to use cut sheets of mother-of-pearl as photographic plates. Although never popularized, perhaps this play with the materiality of light would have been one way to save on the costs of the expensive silver or silver-coppered plates of the daguerreotype. Like indigo, which was sometimes used either as the base or the colorant of photographs of indigo production (Fig. 9), pearl shell and silver-inscribed colonial photographic processes were considered to be two of the major currencies of empire. ${ }^{31}$ Unlike silver and indigo, pearl shell proved too shimmering and too brittle to be put in the service of colonial representation and its media technologies.

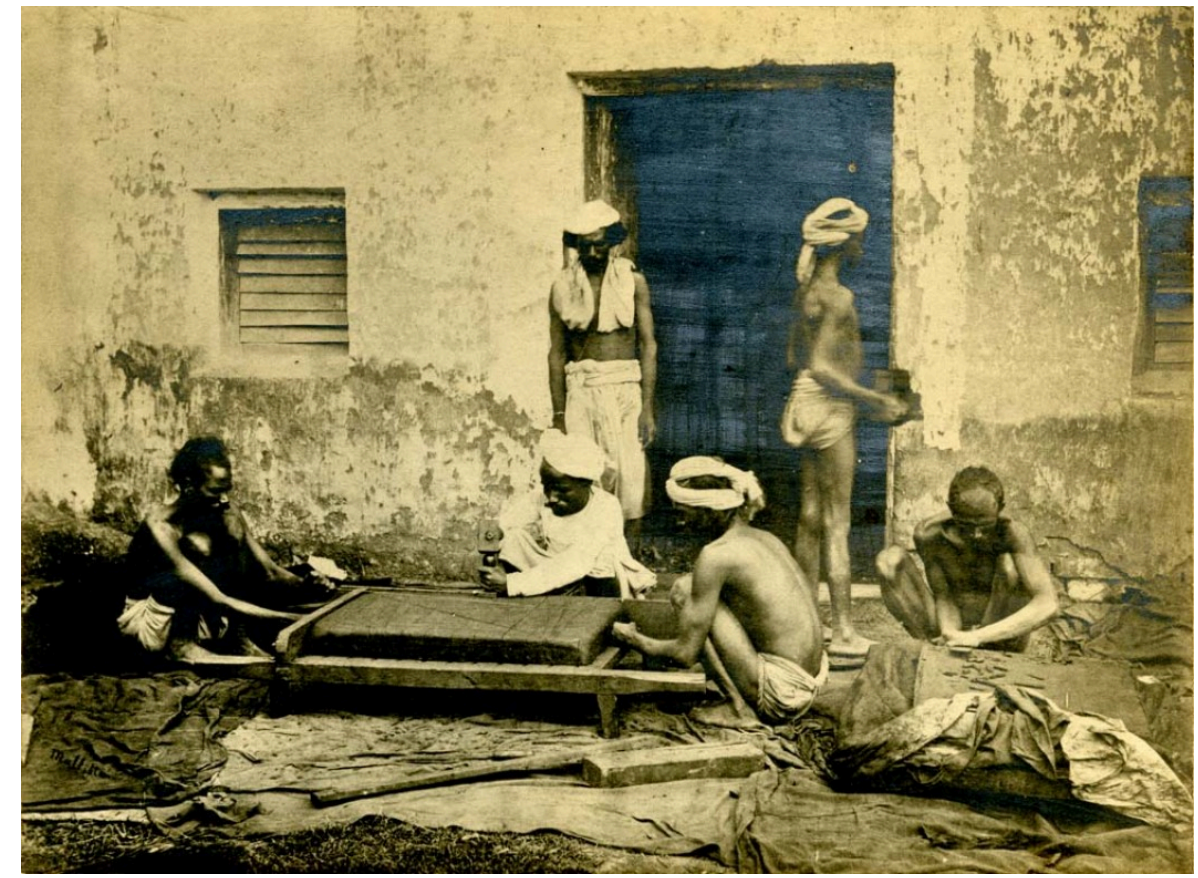

Figure 9.

Oscar Jean-Baptsite Mallite, Indigo cake cutting, Allahabad, India, ca. 1880s. Collection of Royal Botanic Gardens, Kew. Digital image courtesy of Director and the Board of Trustees, Royal Botanic Gardens, Kew. 
But the shimmering nature of pearl would persist in two ways. Pearls and pearlescence really pushed photography. By this, I mean in terms of the kind of light that was involved-the search for the shimmer. The shimmer bears within itself a slight iridescence that incites movement in and of the image. $\underline{32}$ Alongside the careful study of the variegated iridescence of seawater (explored by Franz Boas, most famously), pearl trading had a powerful effect on the entanglement of anthropology and photography. ${ }^{33}$ Branislaw Malinowski's relatively perfunctory photographic practice was radically improved-both in technique and by his visual engagement with the subject-once he encountered the pearl trader Billy Hancock in the Trobriand Islands. $\underline{34}$ At one time, Malinowski captures Billy photographically with a pearl in his left hand. Later he would complain that pearl traders had tried to intervene in the Trobriand kula economy with their crassly made arm shells. Despite this, the pearl trader and the anthropologist playfully exchange places with their respective cameras, or Billy stands shyly (Fig. 10), to the right of Malinowski: "Bill developed 3 rolls all of them good. Only the picture of the two of us is very bad." $\underline{35}$

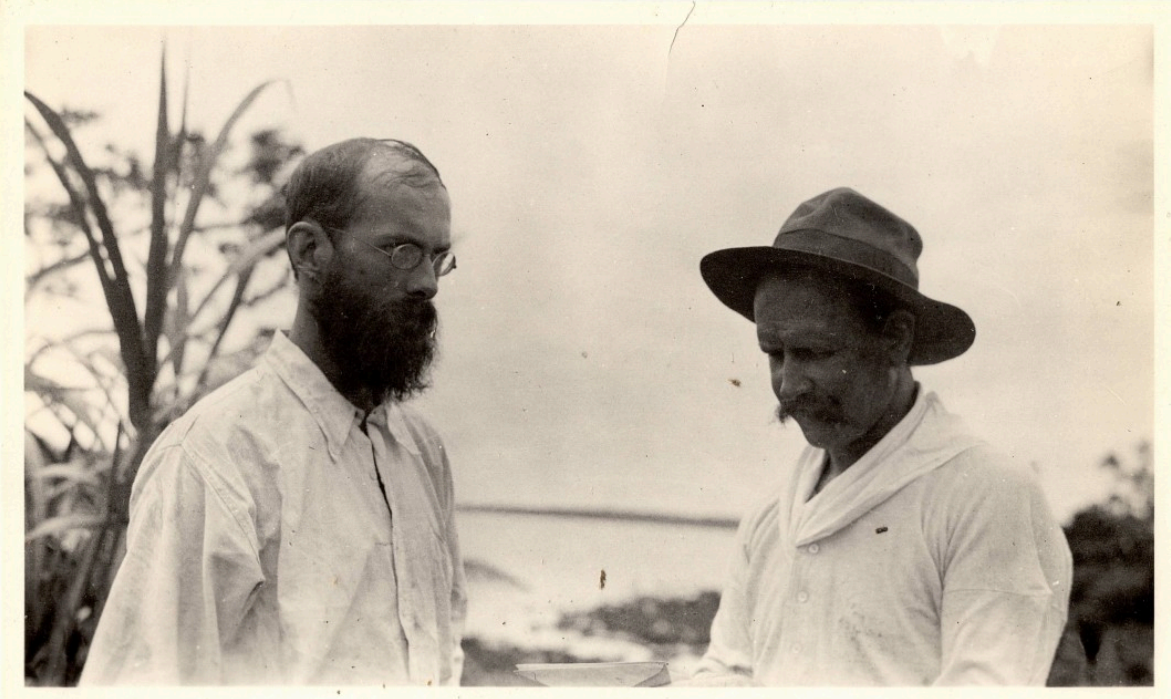

Figure 10.

Unknown creator, Branislaw Malinowski and Billy Hancock, ca. 1918. Collection The London School of Economics (MALINOWSKI/3/25/6). Digital image courtesy of The London School of Economics.

\section{“Unresolvable Oscillations" and the Shark Charmer}

Whilst for Malinowski, it was Billy the creole pearl trader who helped him to experiment with his photographic practice-a practice dominated by the ocean and the shoreline-for Wendt, working a few years later, the diver offduty opened up another way of reading the pearling economy. A crouching 
figure, perhaps a fisherman or diver, dreams of a nubile girl shimmering in the watery depths below (Fig. 11). This languid figure inhabits the economy of sea wives and representations of the trans-oceanic Indian/African goddess,

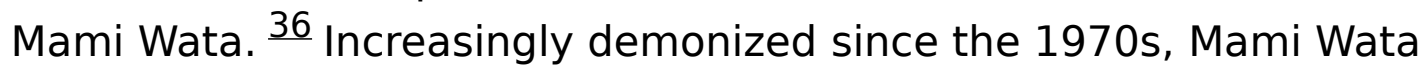
participates in a wider cult of globalizing salt water "fetishisms" and their "unresolvable oscillations". ${ }^{37}$ Certainly in eastern Indonesia, mythical and fetishized sea wives assisted pearl divers and in return demanded storebought goods, which divers could ill afford. $\underline{38}$

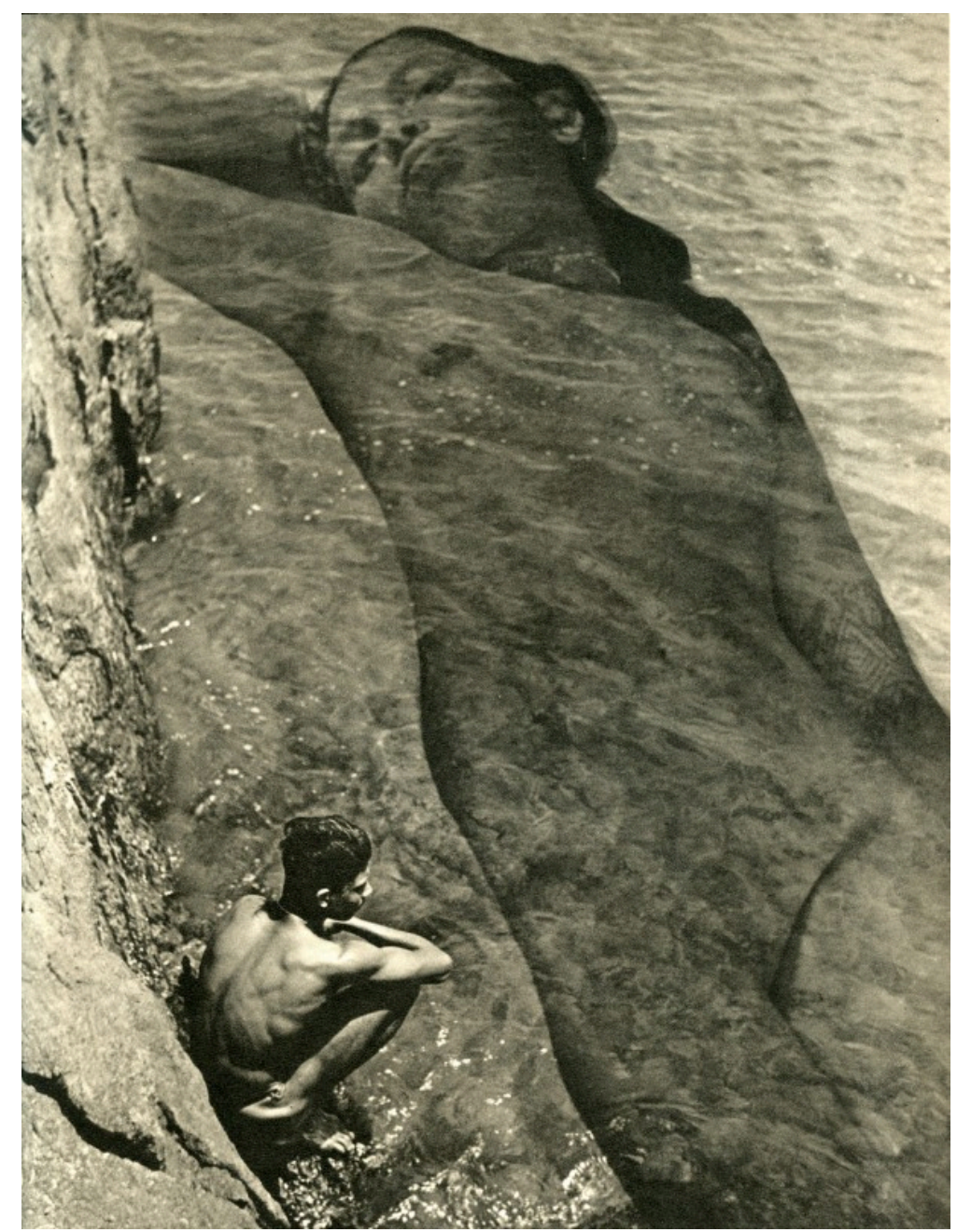

Figure 11.

Lionel Wendt, Dreaming, 1933-34, photogravure, from Lionel Wendt's Ceylon (London, Lincolns-Prager Publishers Ltd, 1950). Digital image courtesy of Lincolns-Prager Publishers Ltd.

The sea wives' presence is still crucial to the workings of local and longdistance commodity trade and debt. In Papua New Guinea, pearl shells "epitomise a kind of cultural metamorphosis that has been central to our understanding and misunderstanding of Melanesian life." $\underline{39}$ Pearl shells are 
either dismissed as emblems of vanity or else they are restricted to a utilitarian purpose. Pearl shells constituted a form of coercive currency as can be seen in the case of pioneering prospectors who flew them over the Papua New Guinea Highlands in their thousands. Kina (Melanesian pidgin for pearl shell) was used in complex patterns of ornament and exchange. White colonialists became enthralled to shell money and the cargo cult which they sought to inflect through the coercive introduction of paper currency from the 1950s. $\stackrel{40}{ }$ Banks and government film companies issued propaganda films and booklets, which sought to justify paper money in lieu of the "inferior" status of pigs and shells, although in the South Highlands, banknotes known as kina notes, were sometimes likened to kina shells. 41

Strangely given this rich anthropological literature, the shell culture of the Gulf of Manaar in the colonial period is relatively absent from discussion, despite the devastating attempts of British colonial authorities to re-engineer

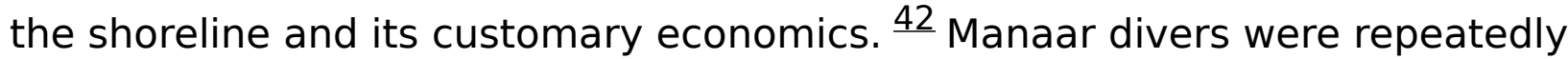
vilified by colonial officials intent on squeezing as much labour from the subaltern body as possible. ${ }^{43}$ Invited to the home of the Gomez family settled at Kilakari, the colonial zoologist, seafaring ethnographer, and the chief colonial official charged with inspecting the pearl fisheries, James Hornell interviewed the local head diver, M. Kirutuneia. M. Kirutuneia claimed to be seventy years old and to have laboured as a pearl diver since he was nine years old. Ever on the relentless search for objective data on the nomadic lives of elusive oysters, Hornell wrote somewhat disappointedly that M. Kirutuneia "had much to say, but few facts of consequence were elicited." $\underline{44} \mathrm{He}$ also complained that very few local men would dive for the British at any time, especially when plans for a second fishing season were introduced:

The divers utilized, with their usual skill, the stalking horse cry of "Sharks on the banks". As any stick is good enough to beat a dog, so any excuse is considered good enough to utilize when the divers for any reason wish a fishery to come to an end. At one time it is "sharks"; at another, the alleged scarcity of oysters, "chippie illei", illness, rumours of cholera, small profits, rough weather, chill winds are all utilized with the utmost cunning but the true reason is that they have made enough money, is always kept in the background. $\underline{45}$

Hornell advocated replacing divers with dredging machines (then being introduced by British colonialists in northern Australia and the Torres Strait). A second alternative would be to lure Arab divers from the Persian Gulf-men he considered more disciplined and able. $\underline{46}$ In "Problems of the Conditions of 
Parawas," Hornell examined what he saw as the inexplicable mestizjo nature of the Parawa (divers) "caste". $\frac{47}{4}$ Although he dedicated much of his career to close empirical study of shell detritus and the lives of oysters, Hornell relies here (as many officials did) on what can be termed the recursive archive. $\frac{48}{\text { It }}$ is as if his analysis of the Parawa caste had to generate afresh the rhetoric of previous colonial accounts:

The Parawas are distinctly brachycephatic whereas the Dravidians who constitute the higher castes in South India are notably longheaded and approximate closely in physical characteristics to the Mediterranean race. The Parawas are probably derived from ancient elements akin to the progenitors of the Polynesians-perhaps the Nagas of the ancient Tamil clerics. $\underline{49}$

According to earlier colonial accounts, "poverty was the compelling power" to dive. ${ }^{50}$ Many men went blind from diving and it seems to have been a common colonial practice to make the blind and the crippled dive until old age or death. Often the British forced divers to dive way too deep-with fatal consequences. In return for their hard labour, which included having to lie on their hard-won bluebottle infested open oysters, waiting for the oyster to rot, which enabled pearls to be extracted, divers could buy small pieces of stone from the local rajahs to establish their own villages. $\underline{51}$ The purchase of local "waste" stone brought with it a certain authority in that the Parawas could then negotiate to elect their own chief, known as the King of the Parawas, if they gifted the local rajah an annual present in lieu of "other" taxes. The king or "don" acquired revenue from districts as far afield as Quilon and Bengal, although the British attempted to reduce his influence and revenue as far as possible. ${ }^{52}$ Not surprisingly, given his fixation with the regulation of the pearl/oyster driven bazaar, which I discuss below, Hornell cited what he believed to be an agreement between the Parawa divers and the local rajah whereby:

guards and tribunals were to be established to prevent all disputes and quarrels arising from this open market, every man being subject to his own judge, and his case being decided by him; all payments are then also divided between the headsmen of the Parawas, who are the owners of that fishery [. . .]. They had weapons and fisheries of their own, with which they are able to defend themselves. $\underline{53}$ 
There was, however, also a magical/nomadic aspect to the rights of the Parawas. Whether Roman Catholics, Muslims, or Hindus, the Parawa divers relied on the powers and presence of the Shark Charmer. Hornell's contemporary Edgar Thurston, the curator of the Madras Government Museum, became fixated with local shamans and what he termed their

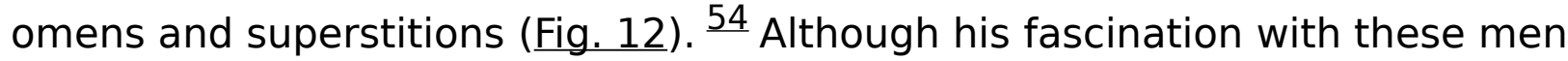
and women was far from unique, what makes his investigations intriguing are his brief discussion of the proximity of the shaman's hut-tied by an electric cable-to the local telegraph pole, and his penchant for collecting silver "Argentine" talismans, which possibly had been used by Parawa divers (Fig. 13). ${ }^{55}$ Perhaps both conjure sympathetic magic as telepathy, which here functions as a disjunctive, hybrid term capturing the British colonial phobia and fetishization of knowledge systems that colonial officials could not fully comprehend. $\underline{56}$

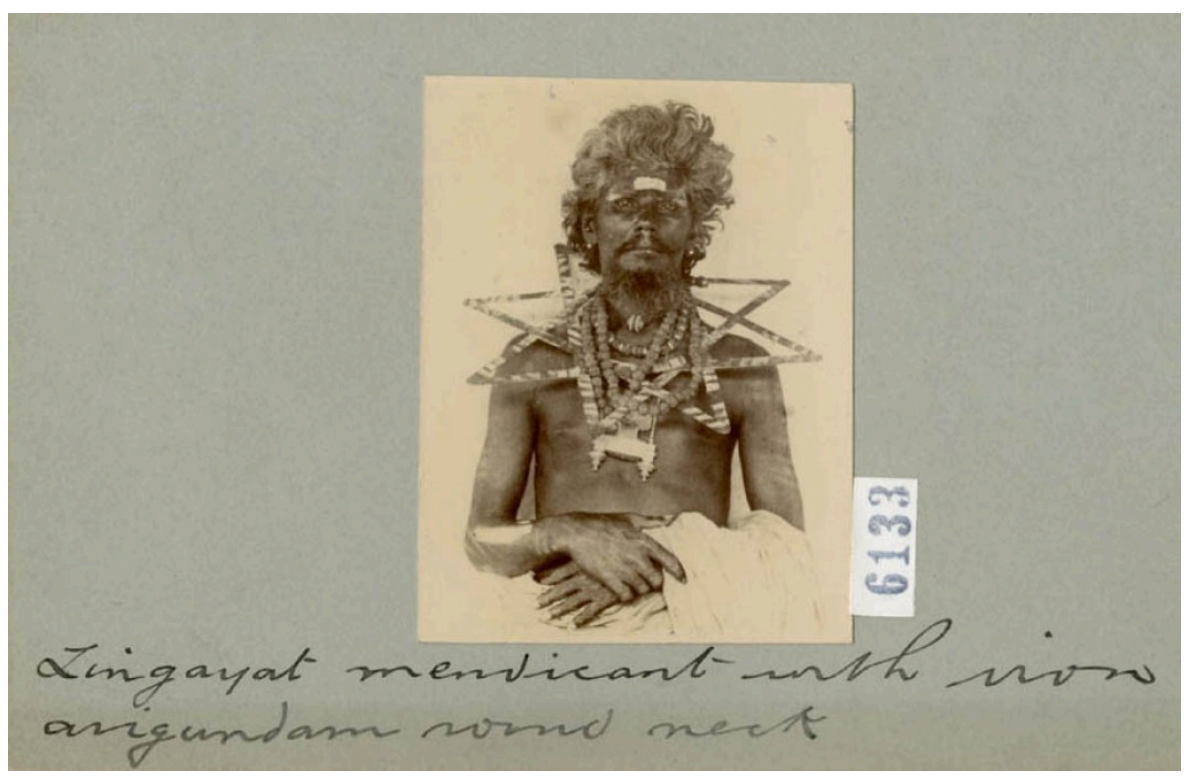

Figure 12.

Edgar Thurston, South Indian Holy Man, ca. 1900-1906. Collection Royal Anthropological Institute, London (RAI 6133). Digital image courtesy of Royal Anthropological Institute. 


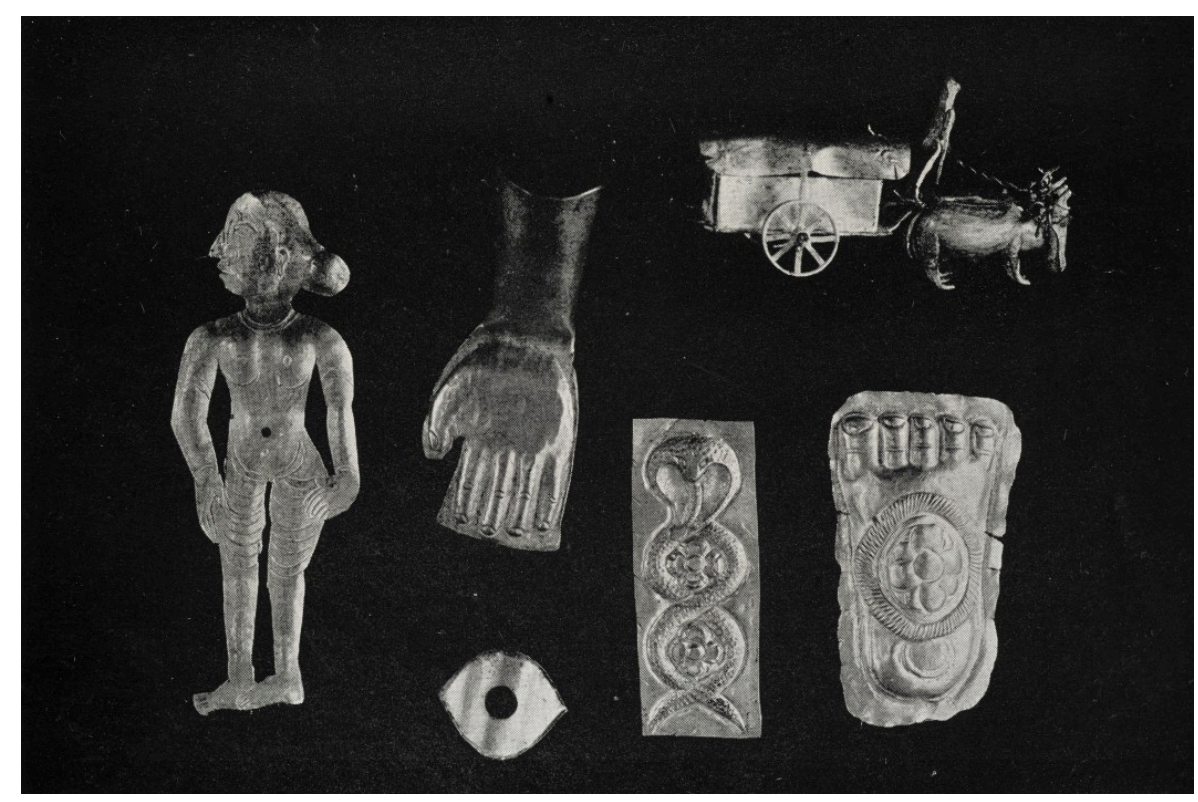

\section{Figure 13.}

Edgar Thurston, Silver South Indian Charms, ca. 1900, from Omens and Superstitions of Southern India by Edgar Thurston (London; Leipsic: T. Fisher Unwin, 1912), facing p. 160. Collection The British Library (T36620). Digital image courtesy of The British Library Board.

Divers would only agree to search for oysters, if they were protected by at least two charmers. Known also as shark binders (kadal-kotti in Tamil; haibanda in Hindustani, or locally as Pillal kadlar), these shamans travelled for the seasonal pearl fishing. Perceived to have extraordinary powers, which also included controlling the winds, the currents, and land animals, the nomadic Shark Charmers often worked in pairs at a distance:

One goes out regularly in the head pilot's boat. The other performs certain ceremonies on shore. He is stripped naked and shut up in a room, where no person sees him from the period of the sailing of the boats until their return. He has before him a brass basin full of water, containing one male and one female fish made of silver. If any accident should happen from a shark at sea, it is believed that one of these fishes is seen to bite the other. The divers likewise believe that, if the conjurer should be dissatisfied, he has the power of making the sharks attack them, on which account he is sure of receiving liberal presents from all quarters. 57

Associated with volt sorcery and sympathetic magic, the Shark Charmer had for centuries held an important place in Portuguese, Dutch, and British territories in southern India and Sri Lanka, and it's certain that without them 
no fisheries would have operated. $\underline{58}$ Verbal descriptions of the charmers describe them as usually tall, dark, long-haired, and wearing beads, with "mysterious characters" marking his arms to resemble a South American medicine man. ${ }^{59}$ Romanticized or otherwise, the figure of the Shark Charmer was the totemic/taboo figure around which the fisheries were organized. They can be glimpsed in photography, if only in terms of the gestalt.

Edgar Thurston observed, in his typically bricoleur manner:

It is recorded by Marco Polo that South Indian pearl divers call in the services of an Abraiman (Brāhman?) to charm the sharks. "And their charm holds good for that day only; for at night they dissolve the charm, so that the fishes can work mischief at their will." [. . .] Before the fishery of 1889, at which I was present, the divers of Kilakarai on the Madura coast, as a preliminary to starting for the scene thereof, performed a ceremony, at which prayers were offered for protection against the attacks of sharks.

"The only precaution," Tennent writes, "to which the Ceylon diver devotedly resorts is the mystic ceremony of the shark-charmer, whose power is believed to be hereditary. Nor is it supposed that the value of his incantations is at all dependent upon the religious faith professed by the operator, for the present head of the family happens to be a Roman Catholic. At the time of our visit, this mysterious functionary was ill, and unable to attend; but he sent an accredited substitute, who assured me that, although he was himself ignorant of the grand and mystic secret, the fact of his presence, as a representative of the higher authority, would be recognised and respected by the sharks."

At the Tuticorin fishery in 1890, a scare was produced by a diver being bitten by a shark, but subsided as soon as a "wise woman" was employed. Her powers do not, however, seem to have been great, for more cases of shark-bite occurred, and the fishery had to be abandoned at a time when favourable breezes, clear water, plenty of boats, and oysters selling at a good price, indicated a successful financial result. $\underline{60}$

Working with the Parawa divers, the charmers encouraged these men to carry an amulet made from a dried palmyra leaf inscribed with mystical characters, which they wrapped in oil cloth. $\frac{61}{1}$ The British attempted to reduce the shark charmers' activities and rewards by stipulating that each shark charmer was only to receive one oyster a day from each diver. 
Nonetheless, they needed the charmers to be present, paying them 9 pence a day and allowing them a choice of the best oysters. $\frac{62}{}$ Only the charmers-also known as "binders" as they had the ability to close the mouths of sharks during daylight hours-could keep divers safe. Shifting sands, migrating oysters, unpredictable currents, and other difficult conditions allow us to characterize these colonial fishing grounds in terms of what Michael Taussig would call miasma-that is, that unruly, ambiguous

space of the abject commons that blurs land, sea, and an invisible city. ${ }^{63}$

\section{The Pearl Fishery Camp as Invisible City}

"Did you ever happen to see a city resembling this one?" Kublai Khan asked Marco Polo $\underline{64}$

Italo Calvino's osmotic chapters on memory, desire, the dead, the sky, the hidden, and the double, etcetera, read as a wonderful palimpsest of the meeting between Kublai Khan and Marco Polo. Fluttering, almost gossamer as a shuffling of miasmic places characterized by hagiographical, occasionally plague-ridden names and tales from chronicles/namas, (Sophronia, Eurtropia, Evsilia, Beersheba, Theordora, Perinthia, Zemrude, Zebeide, Zenobia), these mythical cities can be playfully categorized in terms of the ninth and final category of Jorge Luis Borges's Chinese Encyclopaedique taxonomy as "etcetera". 


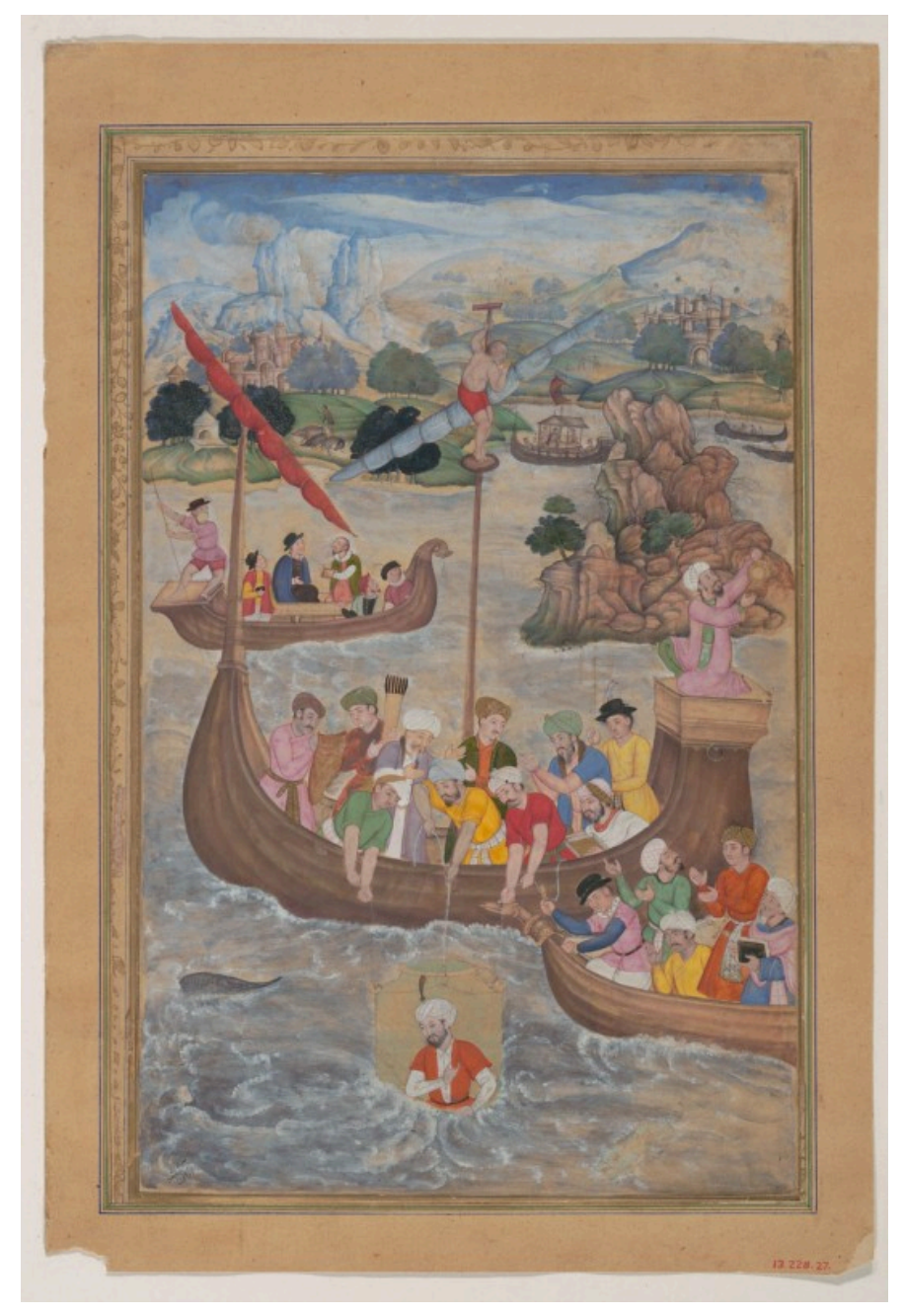

\section{Figure 14.}

Attributed to Mukunda, Alexander is Lowered into the Sea, folio from an illustrated manuscript, 1597-98, ink, watercolor and gold on dyed paper, $23.8 \times 15.9 \mathrm{~cm}$. Collection The Metropolitan Museum of Art, New York (13.228.27). Digital image courtesy of The Metropolitan Museum of Art, New York, Gift of Alexander Smith Cochran, 1913.

As is well known, the Mughal emperor Akbar's chief chronicler Ab'l Fazl (1551-1602) repeatedly revised his own writings for the emperor. He is rumoured to have drawn at least one bird's eye view of the Mughal imperial camp. ${ }^{65}$ This camp (of as many as 200,000 officers, servants, wives, and so on) was in fact two near-identical camps. Described by Ab'l Fazl as having travelled two days or so ahead of the emperor's camp, the doppelgänger camp was intended to provide a kind of horizon line, always just visible to the other following behind. For Ab'l Fazl, writing under his ruler's daily instruction, Akbar himself ultimately embodied the city. Under Ab'l Fazl's direction, Akbar's leading court artists depicted him immersed in a kind of "bell jar" device being lowered to the ocean floor, where he could encounter 
many fish and aquatic monsters. $\underline{66}$ Perhaps not surprisingly, given Akbar's penchant for militant/mythical/heroic forefathers, he also demanded that his court artists portray Iskander (Alexander) observing a beautiful if deadly female sea dragon (Fig. 14).

By contrast, in Western modernity, the camp as the sinister double of the city can be stripped to bare life-at least according to the genealogy laid out by

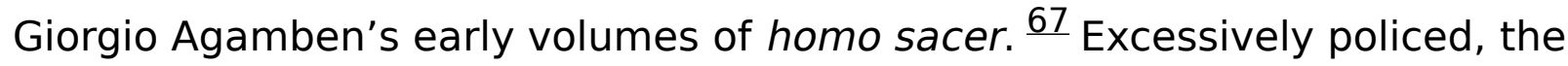
camp is for the twentieth and twenty-first centuries the hideous space of industrial light, torture, and confinement. Agamben's timely intervention has enabled scholars to ruminate on the relationship between the city and the camp, which is most presciently emphasized by academic attention to black sites as "invisible" centres of detention in the USA. One scholarly backlash to the harrowing testimonies of the expanded notion of the camp has been to "redeem" dark, unruly spaces in terms of the "right to opacity". $\underline{68}$ To ruminate on the nomadic aspects of the pearl fishery as camp, the camp is a space which not only incites white racist surveillance but whose "opacity" is instrumental to its very existence.

The boats bristling in the seascape, the temporary camp, and the smattering of Indian and European officials, recall the subject matter and style of Company School painting associated with the north-eastern city of Patna (Azimabad) in India (Fig. 15). These artists had been economically forced by the British to migrate from the courtly karkhāna to the bazaar. Their ambitious Mughal gouache and/or English watercolour views of cityscapes, trade, and religious festivals (melas) would be collected well into the twentieth century (Fig. 16). $\frac{69}{}$ Perhaps mimetically, there is something of such Kampani Qalam in the pearl fishery. $\frac{70}{}$ Although bearing more than a passing resemblance to Patna qalam, it is attributed to the mastico Pondicherry-born artist, Hippolyte Silvaf. 71 


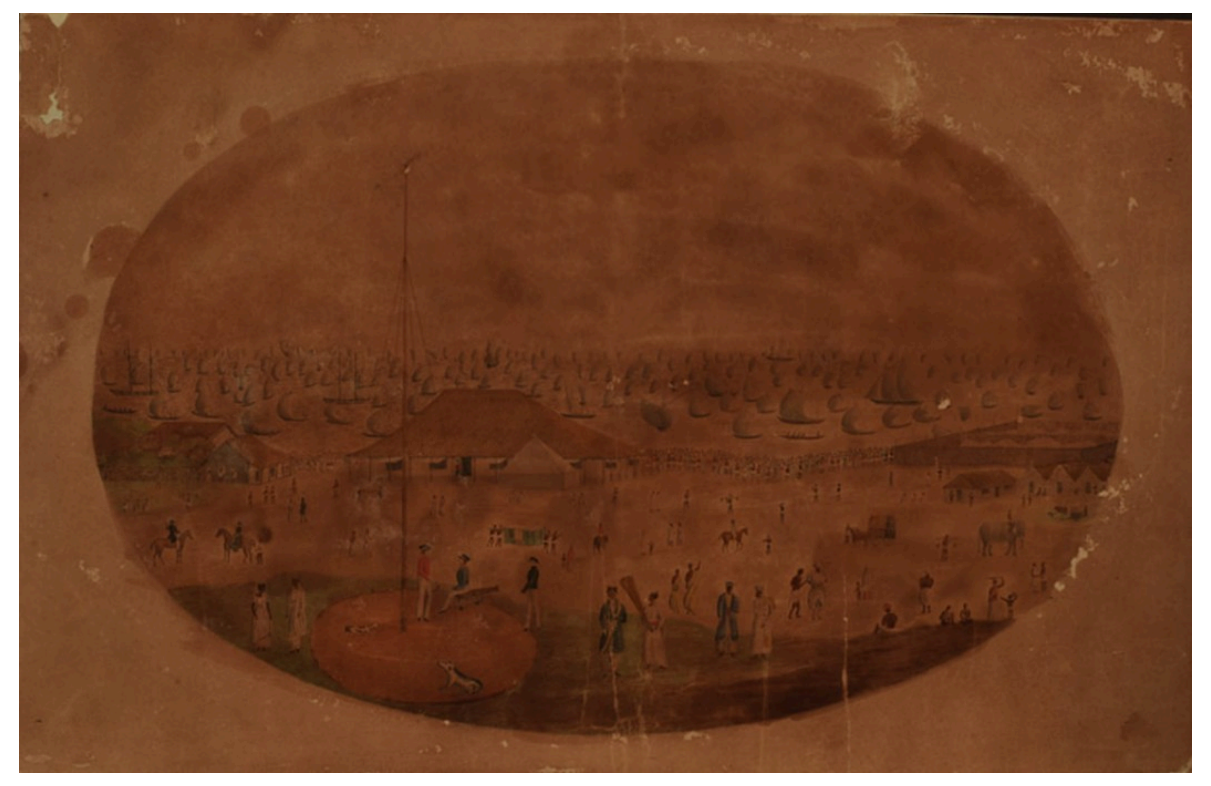

Figure 15.

Hippolyte Silvaf, View of a pearl fishery, Gulf of Manaar, Ceylon, ca. 1840s, watercolour. Collection Colombo National Museum Reserve, Colombo, Sri Lanka. Digital image courtesy of Colombo National Museum Reserve Collection, Colombo, Sri Lanka.

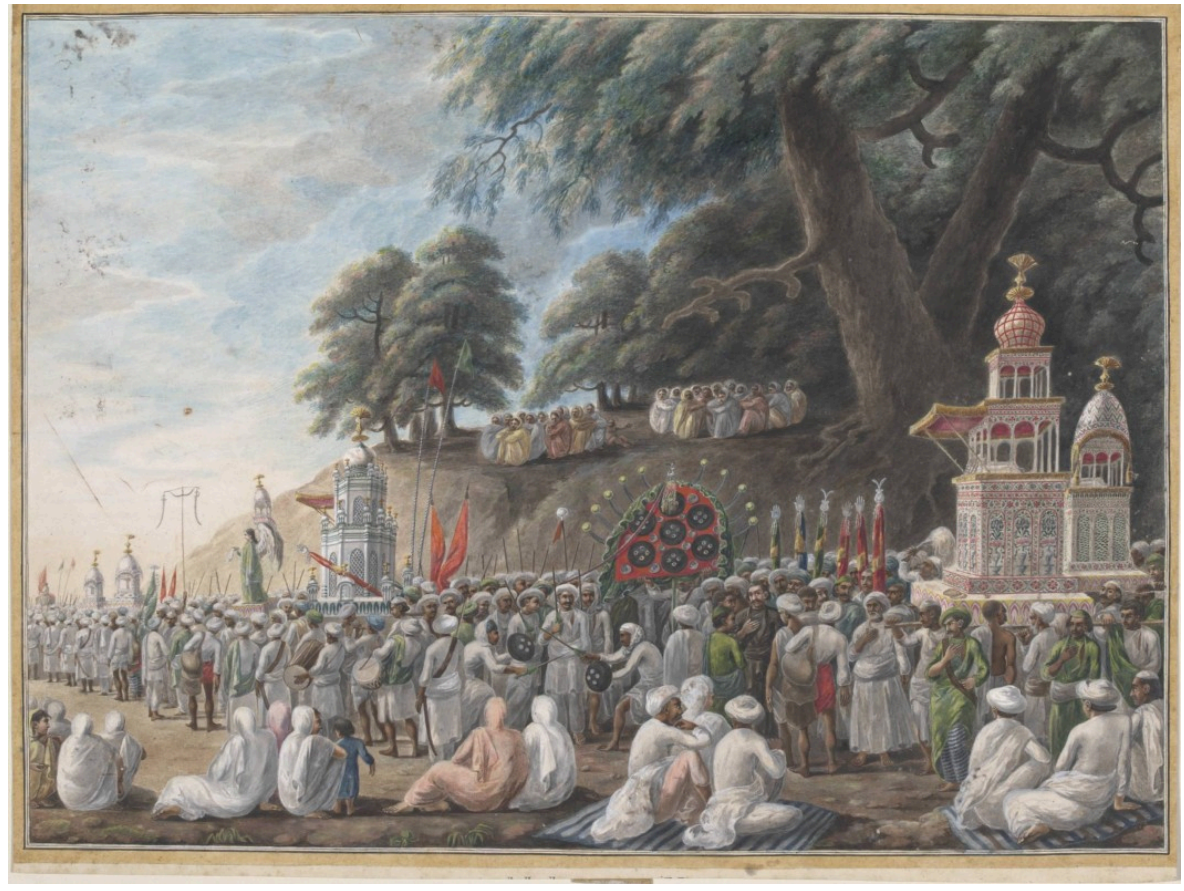

Figure 16.

Unknown creator, A Muharram Scene, a Company painting (made by an Indian artist for the British in India) from the Patna region depicting the Muharram muslim ceremonies, ca. 1807, watercolour on paper, $43.5 \mathrm{x}$ $56.5 \mathrm{~cm}$. Collection Victoria and Albert Museum, London (IS.74-1954). Digital image courtesy of Victoria and Albert Museum, London. 
As well as being one of the few surviving images of the pearl fishery in the Gulf of Manaar, Silvaf's "polyrhythmic" Patna-style painting speaks to the diasporic nature of the north-eastern Indian economy, which played an instrumental role in Manaar's pearl fishery bazaar.

It's not surprising that this diasporic pictorial mimesis extended also to the structure of the Manaar mela/bazaar. The majority of pearl bidders and traders who frequented the Manaar fisheries came from Bihar and Bengal, bringing with them a certain "modular" idea of what constituted the rhythms and structure of the northern and eastern bazaar economy. ${ }^{72}$ To be polyrhythmic is to transgress the expected boundaries of geographical and colonial temporalities; here, this quality stemmed from the archaic nature of labour and the diasporic, sacred nature of the bazaar. The world of the nomadic camp invokes the coming together and displacement of several forms of economy which, as Silvaf's mimicking of Patna painting intimates, is best conceptualized through the mela (religious festival). Whilst it's easy to dismiss the mela as yet another form of the carnivalesque, I suggest that mela as camp-city defined the model of the colonial oceanic economy. Whether pearls, precious stones, or other materials, many goods traded in the bazaar were already sacred. $\underline{74}$ It is not only where "the gods go to market" but also where the nomadic shaman might preside. Although in many respects analogous to Mami Wata, the figure of the Shark Charmer eludes pictorial representation both in the vernacular chromolithographs of the bazaar and in colonial prints, drawings, paintings, and photographs.

Mami Wata perhaps naturally incites something other than visual inscription within an image, even those of the seemingly dull colonial officialdom kind. James Hornell published a few of his own photographs of the pearl camp-city. In a different way to Malinowski's attempt to capture the "filmic" movement of Trobriand rituals, Hornell's blurry images (the originals are lost) juxtapose the quotidian quietude of the camp, with its orderly wide streets-seemingly sparsely peopled and embodying the ideal lines of a cantonment-with the frenzied dumping of oyster shells into the kottu (pearl and pearl shell market enclosure) in the evening. The Manaar pearl fisheries/melas sprung up as sporadic "heterotopias" of up to 50,000 men, women, and children, who set up home and shop around the town of Marichchukkaddi. Living in thatched mud huts, they gathered en masse through word of mouth, rumour, or after the colonial government posted annual advertisements in the press announcing the imminent opening of the fisheries. Travelling from Malabar, Ceylon, the Malay Archipelago, Canton, Madras, and north-east India, this cosmopolitan, subaltern crowd meant for some supporters of British colonialism, "the scum of the East and the riffraff of the Asiatic littoral." $\underline{75}$ 
The camp-as-heterotopia soon came to be highly regulated by British colonial officials. They regularly doused the camp-city with cheap disinfectant, whilst proudly announcing the presence of a police court, jail, bank, post and telegraph offices, auction room, hospital, and cemetery. Heterotopia, as is well known, describes spaces such as beaches, ships, brothels, and colonies in terms of rites of passage, with an emphasis on the imaginary. $\underline{76}$ The beach camp population was regularly counted as part of an attempt in the name of "public peace" to prevent sedition, although regular riots and illicit trading took place. ${ }^{77}$ Avoiding the colonial gaze, divers swallowed pearls, hid shells on their bodies and in the ships' sails; they returned to shore to open shells when they knew the colonial supervisor and his attendants would not be present. They opened as many oysters as possible outside of the colonial tanks into which they were forced, and then closely watched in the activity of shell chucking. Deemed to be looting if caught, the removal of shells without colonial sanction could lead to imprisonment. In an attempt to alleviate some of the stench of rotting oysters in this "black mass of flies" brought to camp daily, the colonial government agreed to finance the amateur inventor G. G. Dixon's Washing Machine. Not particularly efficient, this arcane device became a source of controversy. Under pressure from the British government, colonial authorities in Ceylon and Madras had to agree to lease its fisheries out to the private Ceylon Company of Pearl Fisheries Limited in 1906 , as well as to sell them the machine.

Although yielding the south Indian and Ceylonese colonial authorities' largest single source of income, the fisheries repeatedly failed to produce a regular harvest. Within three years of taking over the Manaar fishery from the Dutch, the British had succeeded in depleting the number of oysters entirely, which led to an anxious spate of articles, public addresses, and reports on the rapid collapse of a potentially lucrative luxury monopoly. In spite of this archival fervour during the nineteenth century, only thirty-six fisheries took place. Colonial officials repeatedly concluded that "the pearl fishery is a branch of revenue too precious a nature to be comprehended at present." $\underline{78}$ Manaar oysters were believed to generate the best pearls when seven years old-just one year before their anticipated death. Their shells, being thin and brittle, were not suitable for the mother-of-pearl market; rather they ended up as "camp filling", chunam or they were ground up and digested along with betel nut (tiny pearls were also chewed, ingested, or spat out in this way). Chunam and betel with areca nut together constituted "a luxury of which all ranks partake". $\underline{79}$ 


\section{Colonial Planning and "Millions of Millions of Pearly Surfaced Shells"}

Given his long-term commitment to the economy of pearls and conch shells, Hornell advocated for the disciplining and punishment of crowds. He chose to make Tondi the modular makeshift city, including a detailed plan of what should constitute the built environment of its shell auction (Fig. 17). The Tondi camp-city, Hornell advocated, would be rigorously regulated in terms of its spatial layout. He believed the presence of a colonial police force was necessary as "The chief trouble experienced was in preventing nuisances along the sea front; after a few examples were made the people learned the necessary lesson and behaved satisfactorily." $\underline{80}$ Aside from the coercive implications of "making an example", the camp included a resident medical officer, who was supposed to assist in the eradication or at least in the containment of cholera and other diseases, which the colonial authorities feared were being spread by the nomadic travels of the camp inhabitants. The hospital should, in all camps, be located at the outermost edge-in Tondi's case, this meant beyond the northern creek. Additionally, the fishery city should include a telegraph, latrines, a water tank, and some kind of "lighting arrangements". Ultimately, "Instead of a large number of miserable oil lamps, a dozen kitson lights were hired". ${ }^{81}$ These vaporized oil burners Kitson Empire Lighting \& Co. claimed to be six times more powerful than oil lights. Such powerful light might have seemed to officials like Hornell as a way of disciplining the shoreline camp, but light "is devious" and luminosity "in itself only makes blacker and more opaque the surrounding darkness." $\underline{82}$ 


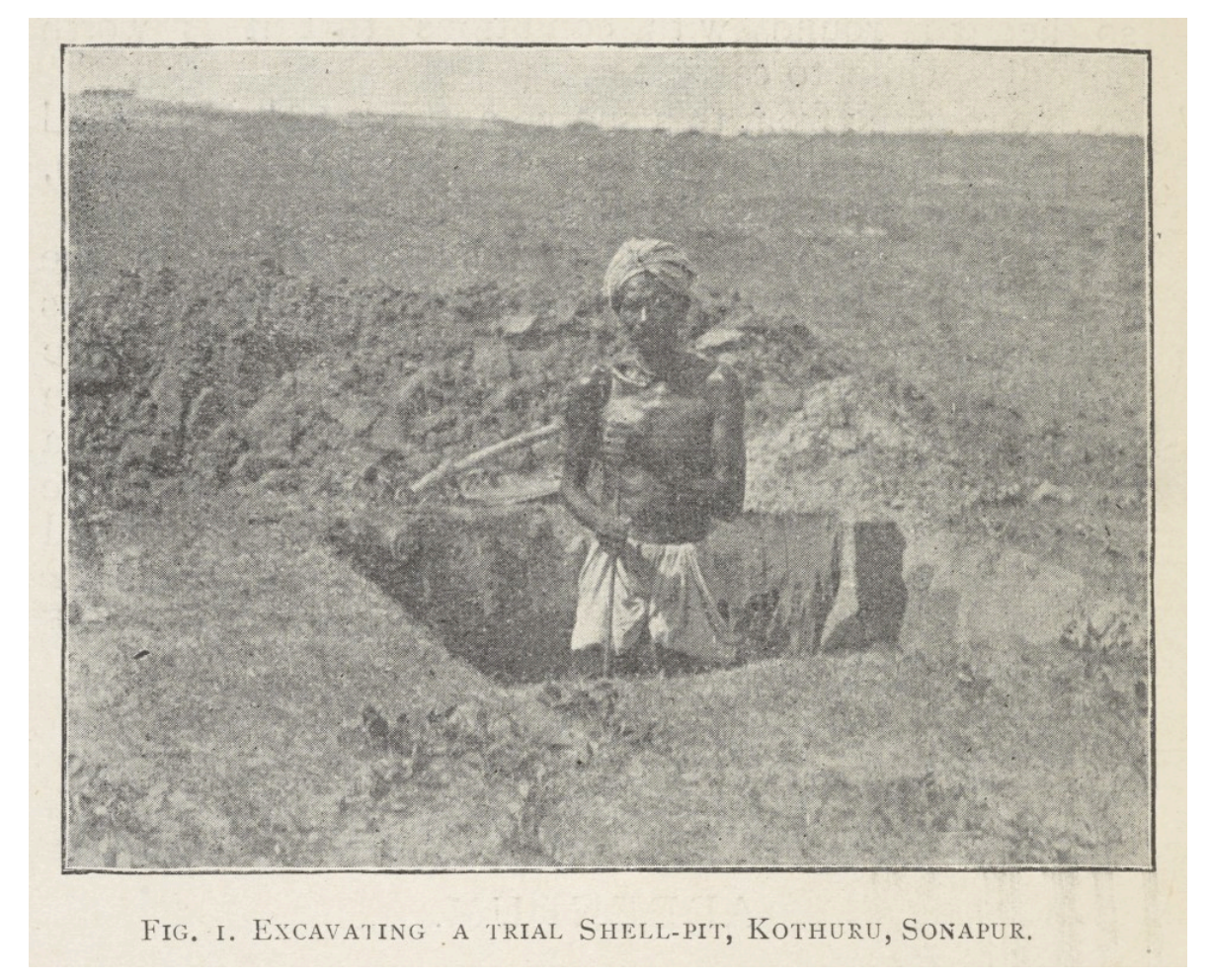

\section{Figure 17.}

James Hornell, Excavating A Trial Shell-Pitt, Kothuru, Sonapur, 1916, from Madras Fisheries Department Bulletin, No. 8 (1916): 126. Collection The British Library (Asia, Pacific \& Africa ST 302). Digital image courtesy of The British Library Board.

Although seemingly dissatisfied with the lighting conditions, Hornell and his fellow colonial officials did not seem too concerned with the aesthetics of these makeshift cities, or with colonial architecture generally, for that matter. As the beacon for the returning fishing boats, casting its shadow over the shore where small girls were made to winnow the sand for pearls (as they also did at Foul Point), stood The Doric. ${ }^{83}$ The Doric-a former British governor's house built in the eighteenth century, and once admired by colonial pearl inspectors for its polite layout and for its glistening oyster chunam lime whiteness-collapsed in the nineteenth century, returning its shell substance to the ocean and to the wind. Whiteness, so exigent to the creole aesthetic of neoclassicism in the colonial cities of Calcutta, Madras, and the Anglican churches of Zanzibar and Singapore, had its origin in the use of ground and burnt shells as plaster in southern Indian temples and shrines. $\frac{84}{}$ Although considered auspicious for millennia in the Gulf of Manaar for the whitewashing of local villages, temples, and shrines, British colonialists complained that chunam lime was too ephemeral, too unstable, and not suited to the desired intricacies of their architectural 
ornamentation-whatever these intricacies might have been, given the dearth of white architects with any knowledge of the tenets of European architecture. $\underline{85}$

The Doric as an architectural order is, after all, the "most basic" and war-like of Vitruvius' "Five Orders". Read less ideologically and more pragmatically, maybe lime was the only material readily available to colonial architects/ engineers: perhaps also, they were unable to comprehend the higher architectural orders, which required greater refinement and a nuanced understanding of a building's load-bearing capacities. The materiality of seashells confounded and eluded colonial practices even though much of the British Empire was built on, or of, Madras lime (chunam). Again, as with the figure of the Shark Charmer, the intelligence, allure, and the lore of the ocean calls to the magical, archaic, worlds of the shell and its "intransigent" materiality.

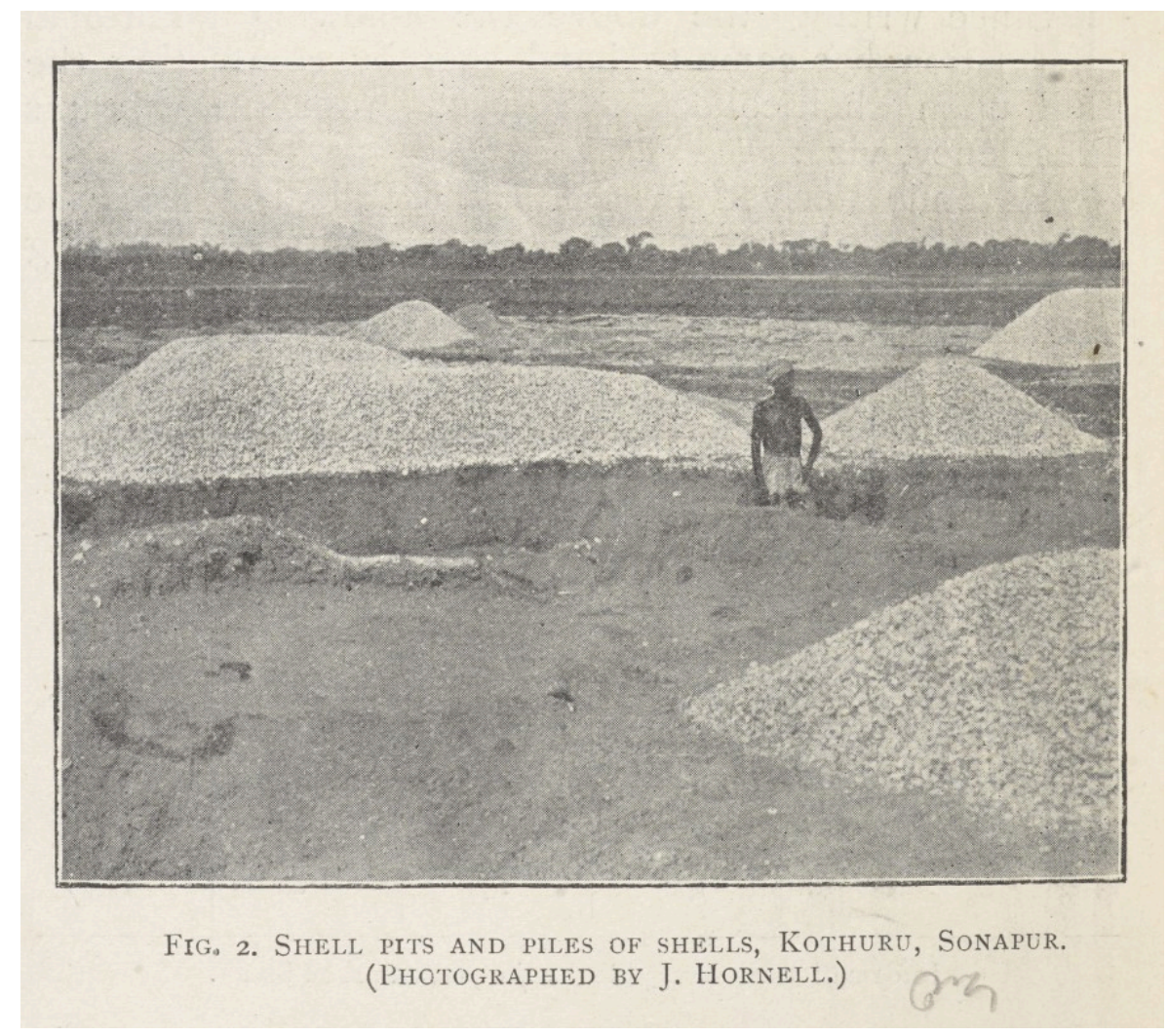

Figure 18.

James Hornell, Shell Pits and Piles of Shells, Kothuru, Sonapur, 1916, from Madras Fisheries Department Bulletin, No. 8 (1916): 126. Collection The British Library (Asia, Pacific \& Africa ST 302). Digital image courtesy of The British Library Board.

Culching (Fig. 18) involved both government-regulated work and a gleaning of the commons. Even if not represented photographically, Parawa women mostly undertook the labour of culching, working under the licence of 
government contractors, who rented the shell pits from the Public Works Department. As payment for their labour, the women could open the molluscs and remove the flesh, which could then be sold to those castes who ate oysters. $\underline{86}$ In a parallel industry, women's marriage jewellery also helped to construct the local villages, shrines, and temples, as the waste from chank shell bangle-making factories at Korkai at the mouth of the Tambaraparni was used in lime making, as can be seen in the mortar of local temple walls. 87 In certain districts in the Gulf of Manaar, everyone had the right to gather shells from the seabeds, although the collection of shells from other sources was increasingly controlled by the colonial authorities. $\underline{88}$ Hornell lamented that: "At present no control is exercised; the miners dig where they like [. . . ]. The ground is unsystematically and wastefully worked." Not surprisingly, given his desire for a modular pearl fishery camp-city, he advocated government-regulated digging. $\frac{89}{}$ Culching usually took place during the dry season, when water levels went down. $\underline{90}$

To walk upon the sward:

The visitor is at first scarcely aware that the nice sward he walks over is but the surface covering millions of millions of pearly surfaced shells. In digging foundations for buildings or cutting lines for the enclosures in which the oysters are placed to putrefy and be examined, the nature of the subsoils is at once shown. Indeed the surface over large areas glistens with fragments of shells. I may add that the shells, when bleached by exposure to sun and rain, assume the beautifully white, lustrous colour which is always associated with the "oriental pearl", as counterdistinguished from the somewhat pinky hued gems of the Red Sea and the Persian Gulf. 91

To culch is also to fill ravines with oyster shells; to make anew the ocean and the shoreline with waste:

The heaps of shells from past fisheries [are] utilized for this purpose, as no great profit could be obtained from removing them to a distance for burning into lime or exporting them to Europe as a material for mother of pearl. The iridescence of the Ceylon pearl-yielding oyster is very beautiful, but the smallness of the shell detracts from its commercial value. $\underline{92}$ 
The Manaar shoreline, which is made up of millions of half-buried shells, still dazzles and shimmers. Is it possible that waste can be redeemed?

\section{Conclusion: Ocean as Intelligence}

Busqué una gota de agua 93

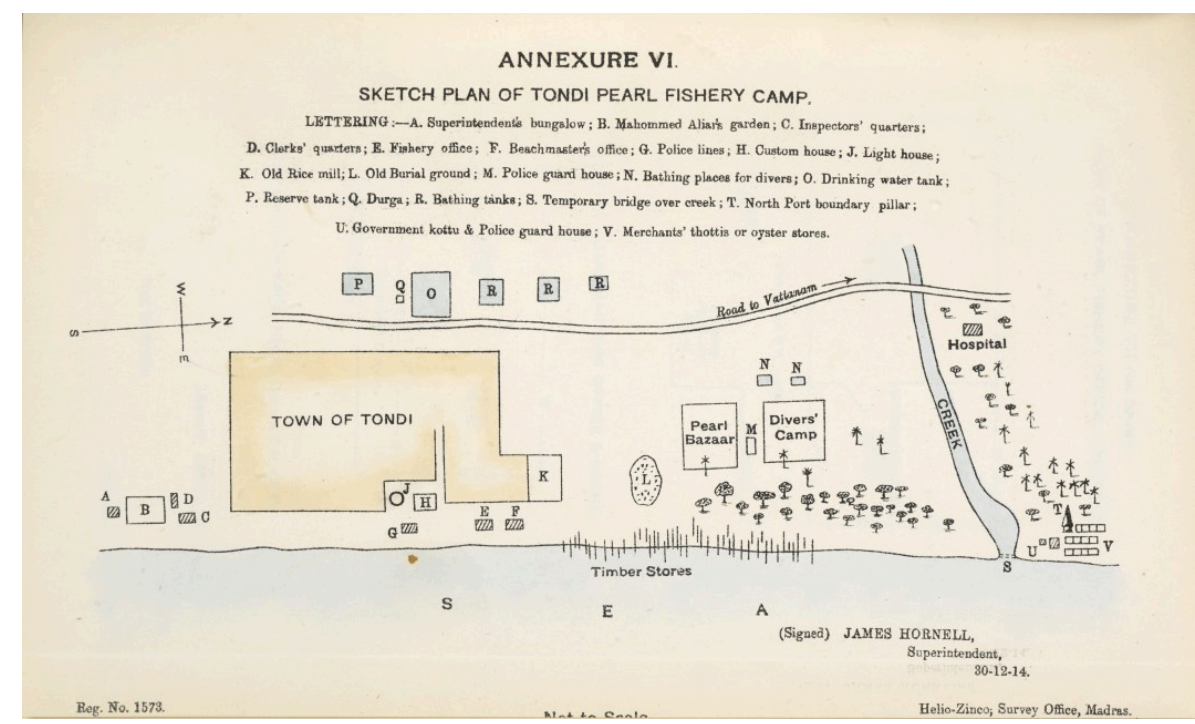

Figure 19.

James Hornell, Sketch Plan of Tondi Pearl Fishery Camp, 1914, from Madras Fisheries Department Bulletin (1916): facing p.92. Collection The British Library (Asia, Pacific \& Africa ST 302). Digital image courtesy of The British Library Board.

Wendt's Silence offers a final, perhaps allegorical photograph of the fate of pearl fishing in the Gulf of Manaar (Fig. 19). Japan and China increasingly dominated the trade in synthetic (fresh) water pearls. For Karl Marx, pearl diving went against the modern trend for artificial pearls bringing to a head the crisis in value. Marx asked: what happens to use value when substances such as wax, glass, or mother-of-pearl attempt to imitate the lustre of seawater pearls? By the time of Marx's writing (his 1844 manuscripts on economics and philosophy), scientists and jewellers were injecting hollow beads of glass with a mixture of liquid ammonia and white matter taken from the scales of fish. The assumed essence/core of the pearl came from crushed herring scales. In terms of the phenomenology of the commodity, this begs the question: "What is value in the light of the development of simulants and the redeployment of rubbish?." 94 Marx's writings on jewels-their simulation and how they might delude the senses-best encapsulates his general theory of species being and labour. $\underline{95}$ Aside from the dumping of opened and unopened oysters in Papua New Guinea and the Gulf of Manaar, oysters 
contributed to the formation of the light of modernity. The Third Reich's experiments with colour and light (the best known example being the concentration camp-based dyes and rubber projects of IG Farben) relied on oyster shells. In 1930s Germany, the pioneering of radiolithic paints produced the desired fluorescence that "allowed Nazi eyes to penetrate the darkness", in ways other than those of the British colonial authorities in Sri Lanka. $\underline{96}$

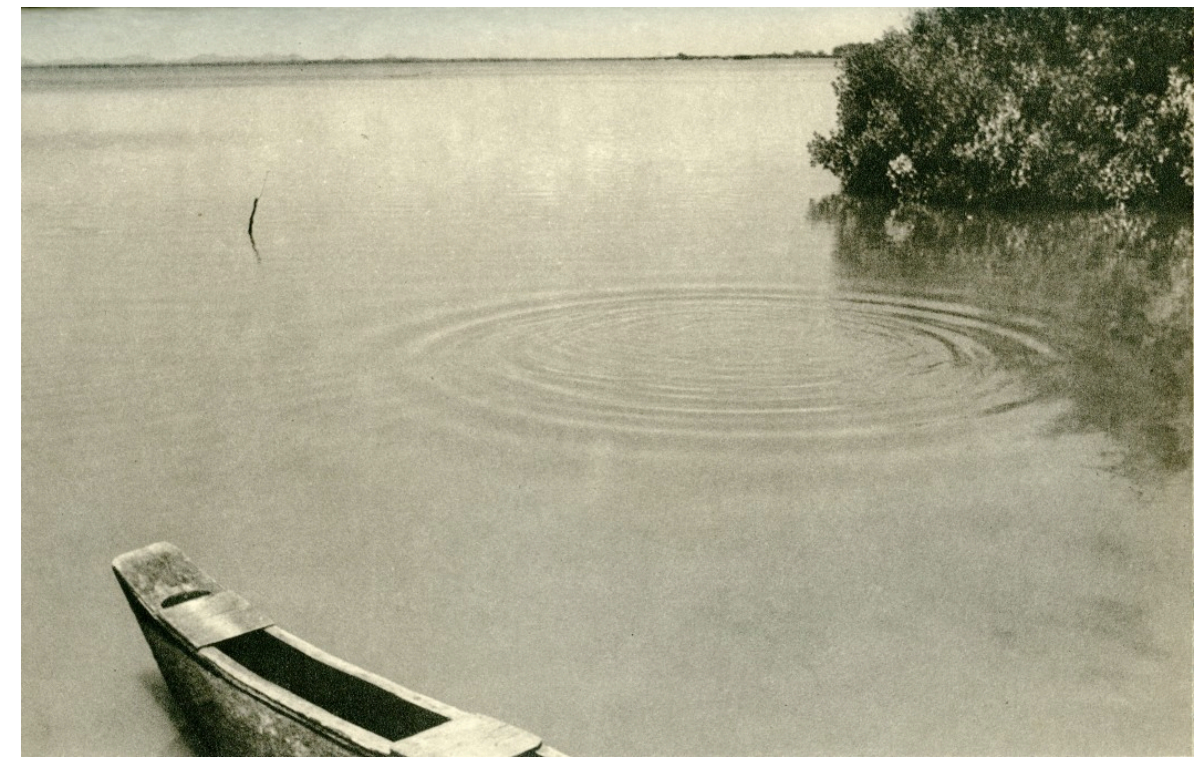

Figure 20.

Lionel Wendt, Silence, ca. 1930s-1940s, photogravure, from Lionel Wendt's Ceylon (London, Lincolns-Prager Publishers Ltd, 1950). Digital image courtesy of Lincolns-Prager Publishers Ltd.

Perhaps it's possible to contemplate this essay's beginning and ending images (Fig. 1 and Fig. 20) as a form of closure in their own right. By the time of the posthumous publication of Lionel Wendt's Ceylon in 1950, photogravure as a technique of reproduction, which was championed by such photographic pioneers as Paul Strand, had been deemed obsolete. 97 Penning Las Piedras del Cielo with a copy of Wendt's slightly faded, blurred, sepia, and bluish plates to hand, for Neruda, the ocean had by 1970 a strain of nostalgia associated with the vanished, vanquished world of the Shark Charmer. $\underline{98}$ Like Wendt's photographs, his melancholic longing is offset by a joyous homage to jewels' shimmering affinity with the ocean: 99

Silence is intensified Into a stone: Broken circles are closed. $\underline{100}$

\section{Footnotes}


2 Pablo Neruda, Piedras del cielo (London: Routledge, 1970), 54. The sea/ocean is a recurrent theme in Neruda's poetry-for instance, his collections The Sea and the Bells, On the Blue Shore of Silence, and The Captain's Verses. See also Sara Contreras and Michel Etienne, "Neruda, poète ou malacologue," Techniques and Culture 29 no. 2 (2012): 45-56.

3 For Wendt, see Ellen Dissanayake, "Renaissance Man: Lionel Wendt-Creator of a Truly Sri Lankan Idiom," Serendib 13 (1994): 1-6; Lionel Wendt: A Centennial Tribute (Colombo: Lionel Wendt Memorial Fund, 2000); Rajit Juroda (ed.), The Gaze of Modernity: Photographs by Lionel Wendt (Fukoka: Fukoka Asian Art Museum, 2003). See also Diva Gujral's poetic "Pictures in the Water: On Time and Memory in Lionel Wendt's Ceylon," unpublished MA dissertation, (University College London, 2015) for Wendt's nostalgia for Europe and ocean-as-memory perceived in a largely Proustian manner. For photographic practice in Sri Lanka, see John Falconer, "19th-century Photography in Ceylon," The Photographic Collector 2, no. 1 (1981): 21-29; Imagining the Isle Across: Vintage Photography from Ceylon (Delhi: The Alkazi Foundation for the Arts, 2015). See also Benita Stambler's online resource "A Guide to Locating Photographs of Colonial Ceylon," November 2014, prepared for the American Institute for Sri Lankan Studies, http://www.aisls.org.

$4 \quad$ Wendt learned how to develop his own film experimenting with photomontage, solarization, and brom-etching. He was the founding member of the Photographic Society of Ceylon (est. 1935). The photographs I discuss in this essay use the technique of photogravure. Wendt wrote extensively in the journal Leica News and Techniques. His most famous work is the posthumously published Lionel Wendt's Ceylon (London: Lincolns-Prager, 1950 and Colombo: Lionel Wendt Memorial Fund, 1950), which was compiled by Bernard A. Thornley with L.C. Van Geyzel. It consists of 120 photographs published with a print run of 5,000. Wendt's photographs in this publication date about 1933 to 1944. It was initially intended to be the first of three volumes; volumes two and three were abandoned because of the financial failure of volume one. It was re-released in 2000 with 110 additional photographs and accompanying essays as A Centennial Tribute.

5 Walcott cited in Krista Thompson, An Eye for the Tropics: Tourism, Photography and Framing the Caribbean Picturesque (Durham, NC: Duke Univ. Press, 2006), 4.

6 Christopher Pinney, Photography and Anthropology (London: Reaktion, 2011); Michael T. Taussig, The Devil and Commodity Fetishism in South America (Chapel Hill, NC: Univ. of North Carolina Press, 1980).

7 For a different take on the importance of the shell, see Charlotte Guichard, "The Shell in the 18th Century: A Border Object?," Techniques and Culture 59, no. 2 (2012): 150-63. This essay appears in a special issue of Techniques and Culture, "Shell Itineraries". Also see Techniques and Culture special issue as a follow up, "Vivre sable!," Techniques and Culture 61 (2013). In this essay, I am more interested in the shell as "waste".

8 The image discussed is available for sale at the oldest surviving firm of photography in Colombo-Plâté \& co. Plâté \& co have a large number of reproduced photographs of labour in Ceylon-primarily of tea and coffee. Pearl fishing amounts to eleven separate photographs; fieldwork, spring 2016.

9 Robert Ryder, "Walter Benjamin's Shell Shock: Sounding the Acoustic Unconscious," New Review of Film and Television Studies 8, no. 2 (2007): 105-55. See also Stefan Helmreich, "Seashell Sound: Echoing Ocean, Vibrating Air, Brute Blood," Cabinet 48 (Winter 2012-13): 8-12. Famously, the Paduan anatomist, Gabrielle Falloppio, described the inner ear in 1561 as the cochea (Latin for snail).

10 Walter Benjamin, Selected Writings, 1935-1938, vol. 3, ed. Paul Bullock and Michael W. Jennings (Cambridge, MA: Harvard University Press, 2002), 374.

11 Antonin Artaud, Oeuvres complètes, vol. III (Paris: Gallimard, 1970); May Helen Kolisyk, "Surrealism, Surrepetition: Artaud's Doubles", October 64 (Spring 1993): 78-90. As well as acting as a model for exploring the (optical) unconscious in modernity, there is a long trajectory of the animated, anthropomorphic, speaking shell. See Charles Williams, Silver-Shell or Adventures of an Oyster (London: Peter \& Galpin, 1857). I discuss aspects of this text below.

12 See Dejan Lukić and Nik Kosieradzki, “The Oyster: In 8 Manifolds" published as an online essay (A Furniture in Motion Pamphlet, published by Rattaplax, 2013). They make the case that the oyster is akin to Deleuze's reading of the monad whilst relating the shell to the principles of Baroque architecture.

13 Most famously, the aquarium is associated with Walter Benjamin's Arcades Project and Aragon's disorientation in the Paris Arcades. For Benjamin, the Arcades were like a dusty fata morgana.

14 See the classic study of Garrett Hardin, "The Tragedy of the Commons", Science 162, no. 3859 (1968): 1243-48; and Bonnie J. McCoy and James M. Acheson (eds), The Question of the Commons: The Culture and Ecology of Communal Resources (Tucson, AZ: Univ. of Arizona Press, 1987); Gísli Pálsson, "The Birth of the Aquarium: The Political Ecology of Icelandic Fishing," in Tim Gray (ed.), The Politics of Fishing (London: Macmillan, 1998), 209-27; Sam Dolbear, "Flooded Displays: The Arcade and the Aquarium", unpublished paper uploaded onto academia.edu.

15 They were known as "Christ Stones" as divers were often associated with both early Christianity (St Thomas) or with Francis Xavier's zealous programme of conversion. From 1740, divers could no longer own their own diving stones; they had to be rented out from the VOC-a practice that continued under the British.

16 During my research in Colombo, the "spectre" of the Tate show was mentioned by several institutional curators and private collectors. Wendt is certainly beginning to garner attention globally.

17 Michael Taussig, "Fieldwork Notebooks: Feld-forschungs-notizbücher," dOCUMENTA 13 (Kassel: Hatje Cantz Verlag, 2012): 45-48. See also Michael Taussig, I Swear I Saw This: Drawings and Fieldwork Notebooks (Chicago, IL: Chicago Univ. Press, 2011).

18 Michael Taussig, My Cocaine Museum (Chicago, IL: Chicago Univ. Press, 2004).

19 Most often associated with the Buddha's third eye, the pearl has been seen as the highest essence of wisdom. Pearls from the region appear in various sources throughout history: the Magawanso Pearls of ... [carry on until] ....and Jules Verne's 20,000 Leagues under the Sea." 
20 Nira Wickramasinghe, Metallic Modern: Early Machines in Colonial Sri Lanka (New York: Berghahn Books, 2014 ), 4.

21 Divers were male which differentiates them from Japanese divers, who were often women. For anonymous photographs of these women divers, see the collection of the Royal Anthropological Institute, London nos. 27531 and 27532. I am grateful to Sarah Walpole for bringing these rare images to my attention. As well as the risk of the bends, divers were frequently subjected to diseases of the lungs and chest, and to deafness. Blood frequently flowed from their mouths, ears, and nostrils. Each dive was around 40 to 50 seconds; divers dived up to sixty times a day, usually at a depth of 6 to 8 fathoms.

22 John Frow, "A Pebble, a Camera, a Man who turns into a Telegraph Pole," Critical Inquiry 28, no. 1 (2001): 270-85; 272.

23 Christopher Pinney, "The Parallel Histories of Anthropology and History," in Elizabeth Edwards (ed.), Anthropology and Photography, 1860-1920 (New Haven, CT: Yale Univ. Press, 1992), 74-95.

24 Sir David Brewster's work on shell iridescence and optics is discussed by Rev. Charles Williams in his intriguing work, Silver Shell, or Adventures of an Oyster, 36. See also David Brewster, Letters on Natural Magic addressed to Sir Walter Scott, Bart. (London: John Murray, 1834); for brief discussion of the use of mother-of-pearl, see David Brewster, The Stereoscope: its History, Theory and Construction with its Application to the Fine and Useful Arts and to Education (London: John Camden Hotten, 1870).

25 Williams, Silver Shell, 36.

26 Williams, Silver Shell, 36.

27 Williams, Silver Shell, 37.

28 Williams, Silver Shell, 37.

29 Williams, Silver Shell, 38. Barton devised an engine on which he engraved, on the surface of steel and metals, lines so minute that from 2,000 to 10,000 could be viewed within a single inch.

30 Williams, Silver Shell, 38-39.

31 See Christopher Pinney's evocative lecture, "Opium, Indigo, Photography," from Berlin Documentary Form 2: New Practices Across Disciplines, at the Haus der Kulturen der Welt, Berlin (31 May-3 June 2012), which is available online. For indigo, cyanide, and sepia in/as colonial photography, see Natasha Eaton, "Subaltern Rustle: Raqs Media Collective, the Colour Blue and the Colonial Archive," MARG 67, no. 1 (September 2015): 13-21. The intriguing photograph I reproduce here is taken, signed (and may be coloured) by Oscar Mallite; the Christopher Rawson collection of photographs of indigo production in the Economic History Botanical Archive at Kew Gardens, London.

32 For theorization of the notion of the shimmer, see Roland Barthes, The Neutral: Lecture Course at the Collège de France (1977-1978), trans. Rosalind E. Krauss and Denis Hollier, text established, annotated, and presented by Thomas Clerc under the direction of Eric Marty (New York: Columbia Univ. Press, 2005), 105-107.

33 Franz Boas wrote his Kiel habilitation of 1888 on seawater. See Stefan Helmreich, "Nature/Culture/Seawater," American Anthropologist 113, no. 1 (2011): 132-44.

34 Billy Hancock traded in what were considered to be valuables (veguwa) for pearls from a local diver. I return to the importance of pearl shells as a major global currency below.

35 This remark is made by Malinowski in his diaries, which were never intended to be published; see Malinowski, $A$ Diary in the Strict Sense of the Term (London: Routledge and Kegan Paul, 1967), 148. There are over 1,100 of Malinowski's photographs in the archives at the London School of Economics, all of which make for fascinating viewing. Billy Hancock is included in the "Encounter" and "The Ethnographer" classifications of this archive. See also Michael W. Young, Malinowski's Kiriwina: Fieldwork Photography, 1915-1918 (Chicago, IL: Chicago Univ. Press, 1998). Malinowski had an ambivalent relationship with Bill(y) Hancock with whom he worked in 1917-18. For instance: "The camera seemed too heavy. I reproached myself for not having mastered the ethnographic situation and Bill's presence hindered me a bit [. . . ]. He thinks this is all very silly"; Malinowski, A Diary, 148.

36 The modern iconography of African "cargo/commodity" goddess Mami Wata was strongly influenced by the Hamburgbased company Adolph Friedlander's 1880s chromolithograph of a Hindu snake charmer Maladamatajaute. At least 12,000 copies were printed in Bombay and sent to traders in Kumase, Ghana to be copied by the Shree Ram Calendar Company. As a transcultural icon, Mami Wata's iconography is frequently merged with that of Lakshmi or the spirit Mami Titi in Ghana, Togo, and Benin. See the exemplary work of Henry John Drewal (ed.), Sacred Waters: Arts for Mami Wata and Other Divinities in Africa and the Diaspora (Bloomington, IN: Univ. of Indiana Press, 2008).

37 It would appear that the cult of Mami Wata is also present in Haiti, Puerto Rica, Brazil, and the Dominican Republic. See Divinatons: Mami Wata Healers Society of North America, http://www.mamiwata.com/divine.html; and http://www.mami-wata.frl. For "fetishisms" and their oscillations/instabilities, see Patricia Spyer (ed.), Border Fetishisms: Material Objects in Unstable Spaces (London: Routledge, 1998), 1.

38 Patricia Spyer, The Memory of Trade: Modernity's Entanglements on an Eastern Indonesian Island (Durham, NC: Duke University Press, 2000).

39 Roy Wagner, Lethal Speech: Daribi Speech as Symbolic Obviation (Ithaca, NY: Cornell University Press, 1984$), 64$.

40 Robert J. Foster, "Your Money, Our Money and the Government's Money: Finance and Fetishism in Melanesia," in Patricia Spyer (ed.), Border Fetishisms: Material Objects in Unstable Spaces (London: Routledge, 1998), 60-96. The term "cargo cult" was first used in the 1950s, in the news magazine Pacific Islands Monthly, as part of a three-sided debate between colonial administrators, expatriate planters, and Christian missionaries. This did have a precedent in German colonies from 1990 onwards. In 1920, the colonial government of Australia issued the Native Currency Ordinance. 
41 Robert J. Foster, Materializing the Nation: Commodities, Consumption, and Media in Papua New Guinea (Bloomington, IN: Indiana Univ. Press, 2002), 41: "The challenge of colonial education lay in teaching a mode of symbolization in which money could be apprehended as a signifier referring beyond itself."

42 For a more general overview of pearl trading in the Gulf of Manaar, see Radhika Gupta, "Changing Courses: A Comparative Analysis of Ethnographies of Maritime Communities in South Asia," Maritime Studies 2, no. 2 (2003): 21-88.

43 Aside from Bizet, Verne, Michelet et al., the British colonial government attempted to generate institutional interest in pearl diving. A government-sponsored aquarium - the Madras Aquarium was established; in the Colombo Museum, Case 31 contained a rather muddled display to do with fishing in which was included a model of a pearl fishing boat and sinking stones from the 1904 fishery. See Anonymous, A Guide to the Collections of the Colombo Museum, Ceylon, Part I Archaeology and Ethnology (Colombo: H. C. Cotte, Government Printer, Ceylon, 1912).

44 James Hornell, "The Indian Pearl Fisheries of the Gulf of Manaar and Palk Bay," Madras Fisheries Bulletin XVI, 1-188 (Madras: Madras Government Press, 1930). Interview 27 April 1904, 64.

45 Hornell, Indian Pearl Fisheries,143-44.

46 Hornell, Indian Pearl Fisheries, 144, and 166-67. For the Persian Gulf and pearls, see Robert A. Carter's thorough Sea of Pearls: 7000 Years of the Industry That Shaped the Gulf (London: Arabian Publishing, 2012).

47 Hornell, Indian Pearl Fisheries, 12. Hornell remained obsessed throughout his career with the relationship between racial profiling and fishing; Hornell, "The Negro as Fisherman," Discoveries (June 1929): 201-205.

48 In Hornell's case, this is most readily apparent in his work "The Indian Pearl Fisheries of the Gulf of Manaar and Palk Bay," where draws heavily on Portuguese and Dutch accounts and economic figures.

49 Hornell, Indian Pearl Fisheries, 12. This kind of physical anthropological analysis had previously been put forward by Herbert Risley and Edgar Thurston.

50 James Cordiner, A description of Ceylon, containing an account of the country, inhabitants, and natural production with narratives of a tour round the island in 1800, the campaign in Candy in 1803, and a journey to Ramisseram in 1804, 2 vols (London: Longman, Hurst, Rees and Orme, 1807), vol. 2, 33-34. This is substantiated by V. Govindan, "Fishery Statistics and Information: West and East," Madras Fishery Bulletin 9 (1916): 120-40. Govindan makes a careful survey of the Gulf of Manaar fisheries, noting the high level of poverty in almost every diving community.

51 Stone was considered to be an inferior building material to shells.

52 By 1891, the king/don was only allowed by the Government to have one boat for pearl diving; Proceedings of the Board of Revenue, Madras, no. 702 (1889).

53 Hornell, Indian Pearl Fisheries, 13.

54 Thurston's intriguing photographs pertaining to southern India are held in the Royal Anthropological Institute, London.

55 So far in my research, I have not found a specific silver charm associated with the Shark Charmer. One reference is made to colonial appropriation or brief sight of such a charm is made by Lt. Col. W. M. G. Colebrooke, in his talk "Observations on the Pearl Fisheries of the Island of Ceylon," published in Proceedings of the Asiatic Journal and Monthly Register for British India 10, no. 29 (2 February 1833): 205-206: "A copy of the talisman, prepared by the Mohamedan shark charmer to protect the divers is annexed." For important critical work on the telegraph, see Richard Taws, "Telegraphic Images in Post-Revolutionary France," Art History 39, no. 2 (2016): 400-21.

56 The word "telepathy" was first coined by the English psychologist Frederic Myers in 1882. Taken literally, it means "feeling from afar" from tele + pathy.

57 Cordiner, A Description of Ceylon, vol. 2, 52.

58 For the Shark Charmer, see The Steubenville Herald, 12 November 1896; Robert Percival, An Account of the Island of Ceylon: Containing its History, Geography, Natural History, with the Manners and Customs of its Various Inhabitants (London: C. and R. Baldwin, 1805), 65-66; Lt. Col. W. M. G. Colebrooke, "Observations on the Pearl Fisheries of the Island of Ceylon," Proceedings of the Societies: The Asiatic Journal and Monthly Register for British India 10, no. 39 (2 February 1833): 305-306. For more recent literature, see Markus Vink, Encounters on the Opposite Coast: The Dutch East India Company and the Nayaka State of Madurai in the 17th Century (Leiden: Brill, 2015), 95 and 639; N. Athiyaman, "Shark Charming: A Magic Act in Pearl Fishery," Indian Historical Studies 10, no. 2 (April 2014): 21-30.

59 Williams, Silver Shell, 77.

60 Edgar Thurston, Notes on the Pearl and Chank Fisheries and Marine Fauna of the Gulf of Manaar (Madras: Madras Government Museum, 1912), 198.

61 E. R. Power, "The Pearl Fishers of Ceylon," in Friendship's Offering (London: Smith, Elder and Co., 1837), 506; James Stueart, An Account of the Pearl Fisheries of Ceylon with an Appendix (Colombo: Government Press, 1843), 15. These charms were often written by the Roman Catholic priests. At this time, each shark charmer received ten oysters a day from each boat.

62 George Frederick Kunz and Charles Hugh Stevenson, The Book of the Pearl: The History, Art, Science and Industry of the Queen of Gems (London: Macmillan \& Co., 1908), 116.

63 Taussig, My Cocaine Museum, 45-56.

64 Italo Calvino, Invisible Cities

65 Ab'l Fazl, Akbarnama, trans. and edited by Henry Beveridge, 2 vols (Delhi: Rare Books, 1972), vol. 1, 123. 
66 See Maurice S. Dimand, "Mughal Painting under Akbar the Great," The Metropolitan Museum of Art Bulletin, New Series, 12, no. 2 (1953): 46-51.

67 Giorgio Agamben, Homo Sacer: Sovereign Power and Bare Life (Stanford, CA: Stanford Univ. Press, 1998); and Agamben, Remnants of Auschwitz: The Witness and the Archive, trans. Daniel Heller-Roazen (New York: Zone Books, 2002). Agamben's project on bare life consists of eight volumes; seven have been published (out of volume order) so far. For an interpretation of Agamben on the camp in relation to Judith Butler and Hannah Arendt with insightful citations relating to the thresholds of the topological and the topographical, see François Debrix, "Topologies of Vulnerability and the Proliferation of Camp Life," Environment and Planning D: Society and Space 33, no. 3 (2015): 444-59; T. Campbell, Improper Life: Technology and Biopolitics from Heidegger to Agamben (Minneapolis, MN: Univ. of Minnesota Press, 2011).

68 Edouard Glissant, quoted in T. J. Demos, The Migrant Image: The Art and Politics of Democracy During Global Crisis (Durham, NC: Duke Univ. Press, 2013), 132.

69 For Patna qalam, see Mildred Archer, Patna Painting (London: Royal Asiatic Society, 1947) and Rebecca M. Brown, “Colonial Polyrhythm: Imagining Art in Early 19th-Century Patna," Visual Anthropology 26, no. 4 (2013): 269-97.

70 The watercolour was included as part of a presentation copy of James Steuart's Pearl Fisheries of Ceylon, dated 1837. The watercolours of the pearl fishery at Arippu, including his life-size depictions of pearl oysters, were stolen from the Royal Commonwealth Library Collection, Cambridge University Library.

71 Born Phillip Antoine Hippolyte Silvaf or Sylvaf, Silvaf supposedly came from Pondicherry. He worked as a medical draughtsman in Sri Lanka for twenty years. He was a freelance portraitist and watercolourist. He also provided work for The Illustrated London News. He gave lessons in French and music and he tuned pianos. He was also the art tutor of the well-known Dutch, Sri Lankan-born painter, John Leonard Kalenberg Van Dort, who also worked in Colombo. A few of Silvaf's works are reproduced in the journal Young Ceylon 1, no. 1. It has been suggested that he travelled to Manaar in the 1850s and that he established a school in Kandy. In addition to what I have noted above, important works also stolen from Cambridge University Library include eleven drawings from his work Costumes of Ceylon. It would, however, appear that fifteen postcard-size prints were taken from these images, which appear in Alistair Mackenzie Ferguson's Souvenirs of Ceylon: A Series of One Hundred and Twenty Illustrations of the Varied Coast, River, and Mountain Scenery of the Beautiful "Eden of the Eastern Wave" (Colombo: A. M. Ferguson, 1868). Much of Silvaf's work relating to his time in the Gulf of Manaar is uncatalogued in the National Museum of Sri Lanka. The museum recently paid $\$ 40,000$ for two small albums of his exquisite fish drawings. The art scene in nineteenth- and twentieth-century Sri Lanka is relatively underexplored by scholars. See R. K. de Silva's extensive cataloguing of Sri Lankan art exemplified by his comprehensive book 19th-Century Newspaper Engravings of Ceylon-Sri Lanka (London: Serendib Publications, 1998), which includes reference to Silvaf and K. Warnapala, "Caricaturing Colonial Rule in Sri Lanka: An Analysis of Muniandi, The Ceylon Punch," Early Popular Visual Culture 10, no. 3 (2012): 3-56; and Kanchaneskes Warnapala, "The Portraits of the Colonial Artist in Sri Lanka," Internations 14 (2012): 54-87. Although not a popular subject for colonial representation, pearl fisheries do feature as a subject in their own right as photographs by late nineteenth- early twentieth-century Jaffna-born professional photographer Adolphus William Andrée's work. He worked mostly in Jaffna and Slave Island.

72 There is a wealth of economic/social history on the bazaar in northern and eastern India. Most relevant here are C. A Bayly, Rulers, Townsmen and Bazaars: North Indian Society in the Age of British Expansion, 1770-1870 (Cambridge: Cambridge Univ. Press, 1983); Rajat Kanta Ray, "Asian Capital in the Age of European Domination: The Rise of the Bazaar, 1800-1914," Modern Asian Studies 29, no. 3 (1995), 449-554; Anand Yang, Bazaar India: Markets, Society and the Colonial State in Bihar (Berkeley, CA: Univ. of California Press, 1998); and Sudipta Sen, Empire of Free Trade: The East India Company and the Making of the Colonial Market Place (Philadelphia, PA: Univ. of Pennsylvania Press, 2008).

73 For British colonial attempts to incorporate the mela into their notions of economy, see Yang, Bazaar India, 150.

74 For the argument on how gods go to market and vernacularizing capitalism, see Jain, Gods in the Bazaar.

75 Kunz and Stevenson, The Book of the Pearl, 109.

76 Michel Foucault, “Of Other Spaces,” Diacritics 16, no. 1 (1986): 3.

77 A. M. and J. Ferguson, All About Gold, Gems and Pearls in Ceylon and South India (London: A. M. and J. Ferguson, 1888), 172.

78 R. Colebrooke, An Account of the Pearl Fisheries of Ceylon (London, 1831), 64.

79 Cordiner, A Description of Ceylon, vol. 2, 98.

80 Hornell, Indian Pearl Fisheries, 83. The police were given their own "district" lines, which housed seventy-five constables. They were divided from what the colonial government referred to as the "coolie lines". The main purpose of the presence of the police was to guard the government kotthu and the pearl bazaar. For the classic study of colonial lines, see Veena Oldenberg, The Making of Colonial Lucknow, 1856-1877 (Cambridge: Cambridge Univ. Press, 1984).

81 James Hornell, "The Utilization of Coral and Shells for Lime Building in the Madras Presidency," Madras Fisheries Bulletin 8 (1914-15): 84.

82 Esther Leslie, Synthetic Worlds: Nature, Art and the Chemical Industry (London: Reaktion, 2005), 161.

83 Cordiner, Description of Ceylon, vol. 2, 60. 
84 For brief reference to the use of "Madras chunam" in Anglican church building, see G. Alex Bremner, Imperial Gothic: Religious Architecture and High Anglican Architecture in the British Empire (New Haven, CT: Yale Univ. Press, 2013), 167-68. He notes the difficulties of working with chunam as a building material, that it was almost impossible to drill a nail throughout it, see 167. It was prepared by adding shell lime which must not include sand, which is then beaten with egg whites and coarse sugar to make a kind of paste to which water in which coconut shells had been soaked is then added to the mixture.

85 Although British colonial architecture erred towards the Doric or the Ionic order, in the Gulf of Manaar region, this might not have referred so much to either the "orthodox Vitruvian order" or the "stoic" revival of the more war-like order, which had ideological ramifications, as seen in the proliferation of the Doric order in early nineteenth-century British architecture in Scotland for instance, as to the lack of colonial ability to grapple with shell lime as the material of the "higher" architectural orders. The simpler the structure, the cheaper to fix or destroy it would be. Perhaps in this way, colonial cities were not unlike the pearl fisheries camps. Bremner makes the important point that for the Anglican church, stone had always been the primary material chosen. But in a colonial context, it just did not weather-as opposed to shell lime.

86 Hornell, "The Utilization of Coral and Shells for Lime Building," 113.

87 Hornell, "The Utilization of Coral and Shells for Lime Building," 123-24. Chank shells were also in high demand in Bengal as marriage bangles. This was another reason why so many north-east Indian traders travelled to the Gulf of Manaar.

88 Hornell, "The Utilization of Coral and Shells for Lime Building," 14. For instance, in the Guntur and Kistna districts, Rs 2,443 was credited to the Government as rental dues.

89 Hornell, "The Utilization of Coral and Shells for Lime Building," 114. Hornell sought out areas for digging near Puttar. Culching usually took place during the dry season, when water levels went down. But to find anyone to dig proved difficult.

90 Hornell, "The Utilization of Coral and Shells for Lime Building," 106.

91 Fergusson, All About Gold, 381.

92 Ferguson, All About Gold, 381.

93 Pablo Neruda, Las Piedras del Cielo, "Poem VI"

94 Leslie, Synthetic Worlds, 14.

95 Leslie, Synthetic Worlds, 72.

96 Leslie, Synthetic Worlds, 235.

97 Photogravure is an intaglio printmaking or photo-mechanical process, whereby a copper plate is coated with a lightsensitive gelatin tissue which had been exposed to a film positive, and then etched, resulting in a high quality intaglio print that can reproduce the detail and continuous tones of a photograph.

98 No more diving for pearls has taken place since 1962. Dr N. Athiyaman and Dr Justin Wilson recently undertook fieldwork in the Gulf of Manaar to investigate divers' rituals, interviewing 100 diverse divers of ages ranging from thirty-one to eighty (2013-14). Although divers still pray, there is no evidence of the Shark Charmer today. Through hearsay, they discovered that the Shark Charmer might have been most recently present at the village of Eral near Tuticorn, only to find the village deserted and in ruins. Dr Thanajayan of Palayankottai has also undertaken work on the rituals of the Parawa (Parathava community).

99 The search for water is a recurrent them in Neruda's Las Piedras del Cielo. See, for instance, Las piedras, 13, “Poem II" on quartz-quartz being particles of sand: "Quartz opens its eyes in the snow / And grows spiky, / Slipping on the white / Into its own whiteness: / Multiplying the mirrors / It poses in facets, at angles: / White sea urchins / From the depths, / It is the son of the salt / That shoots up to heaven / Glacial orange blossom / Of silence, / Very principle of foam ...."

100 Pablo Neruda, Piedras del Cielo Poem XIX

\section{Bibliography}

Ab'l Fazl, Akbarnama, trans. and edited by Henry Beveridge, 2 vols. Delhi: Rare Books, 1972.

Agamben, Giorgio. Homo Sacer: Sovereign Power and Bare Life. Stanford, CA: Stanford University Press, 1998.

Agamben, Giorgio. Remnants of Auschwitz: The Witness and the Archive, trans. Daniel Heller-Roazen. New York: Zone Books, 2002.

Alkazi Foundation for the Arts. Imagining the Isle Across: Vintage Photography from Ceylon. Delhi: The Alkazi Foundation for the Arts, 2015.

Anonymous. A Guide to the Collections of the Colombo Museum, Ceylon, Part I Archaeology and Ethnology. Colombo: H. C. Cotte, Government Printer, Ceylon, 1912.

Archer, Mildred. Patna Painting. London: Royal Asiatic Society, 1947.

Artaud, Antonin. Oeuvres complètes, vol. III. Paris: Gallimard, 1970.

Athiyaman, N. "Shark Charming: A Magic Act in Pearl Fishery." Indian Historical Studies 10, no. 2 (April 2014): 21-30. 
Barthes, Roland. The Neutral: Lecture Course at the College de France (1977-1978), trans. Rosalind E. Krauss and Denis Hollier. New York: Columbia University Press, 2005.

Bayly, C. A. Rulers, Townsmen and Bazaars: North Indian Society in the Age of British Expansion, 1770-1870. Cambridge: Cambridge University Press, 1983.

Benjamin, Walter. Berlin Childhood Around 1900, trans. Howard Eiland. Cambridge, MA: Harvard University Press, 2006. Benjamin, Walter. A Little History of Photography. London: Penguin, 1978, 1st edn 1930.

Benjamin, Walter. "The Work of Art in the Age of its Mechanical Reproducibility." In Walter Benjamin, Illuminations, trans. Harry Zohn. London: Penguin, 1970.

Benjamin, Walter. Selected Writings, 1935-1938, vol. 3, eds Paul Bullock and Michael W. Jennings. Cambridge, MA: Harvard University Press, 2002.

Bremner, G. Alex. Imperial Gothic: Religious Architecture and High Anglican Architecture in the British Empire. New Haven, CT: Yale University Press, 2013.

Brewster, David. Letters on Natural Magic addressed to Sir Walter Scott Bart. London: John Murray, 1834.

Brewster, David. The Stereoscope: its History, Theory and Construction with its Application to the Fine and Useful Arts and to Education. London: John Camden Hotten, 1870.

Brown, Rebecca M. “Colonial Polyrhythm: Imagining Art in Early 19th-Century Patna." Visual Anthropology 26, no. 4 (2013): 269-97.

Calvino, Italo. Invisible Cities. London: Penguin, 2016.

Campbell, T. Improper Life: Technology and Biopolitics from Heidegger to Agamben. Minneapolis, MN: University of Minnesota Press, 2011.

Carter, Robert A. Sea of Pearls: 7000 Years of the Industry that Shaped the Gulf. London: Arabian, 2012.

Chaudhury, Zahid R. Photography in Nineteenth-Century India. Minneapolis, MN: University of Minnesota Press, 2012.

Colebrooke, Robert. An Account of the Pearl Fisheries of Ceylon. London, 1831.

Colebrooke, W. M. G. "Observations on the Pearl Fisheries of the Island of Ceylon." Proceedings of the Asiatic Journal and Monthly Register for British India 10, no. 29 (2 February 1833): 205-206.

Contreras, Sara and Etienne, Michel. "Neruda, poète ou malacologue." Techniques and Culture 29, no. 2 (2012): 45-56.

Cordiner, James. A Description of Ceylon, containing an account of the country, inhabitants, and natural production with narratives of a tour round the island in 1800, the campaign in Candy in 1803, and a journey to Ramisseram in 1804. 2 vols. London: Longman, Hurst, Rees and Orme, 1807.

Debrix, François. "Topologies of Vulnerability and the Proliferation of Camp Life." Environment and Planning D: Society and Space 33, no. 3 (2015): 444-59.

Demos, T. J. The Migrant Image: The Art and Politics of Democracy during Global Crisis. Durham, NC: Duke University Press, 2013.

Dewan, Deepali. Embellished Reality: Painted Photographs. Ontario: Royal Ontario Museum, 2011.

Dimand, Maurice S. "Mughal Painting under Akbar the Great." The Metropolitan Museum of Art Bulletin, New Series 12, no. 2 (1953): 46-51.

Dissanayake, Ellen. “Renaissance Man: Lionel Wendt-Creator of a Truly Sri Lankan Idiom." Serendib 13 (1994): 1-6.

de Silva, R. K. Nineteenth-Century Newspaper Engravings of Ceylon-Sri Lanka. London: Serendib Publications, 1998.

Drewal, Henry John (ed.). Sacred Waters: Arts for Mami Wata and Other Divinities in Africa and the Diaspora. Bloomington, IN: University of Indiana Press, 2008.

Eaton, Natasha. "Subaltern Rustle: Raqs Media Collective, the Colour Blue and the Colonial Archive." MARG 67, no. 1 (September 2015): 1-8.

Edwards, Steve. The Making of English Photography, Allegories. University Park, PA: Pennsylvania State University Press, 2006. Elkins, James. What Photography Is. London: Routledge, 2011.

Falconer, John. "Nineteenth-Century Photography in Ceylon." The Photographic Collector 2, no. 1 (1981): 21-29.

Falconer, John and Raheem, Ismeth. Regeneration: A Reappraisal of Photography in Ceylon, 1850-1900, London: British Council, 2000.

Ferguson, A. M. Souvenirs of Ceylon: A Series of One Hundred and Twenty Illustrations of the Varied Coast, River, and Mountain Scenery of the Beautiful "Eden of the Eastern Wave". Colombo: A. M. Ferguson, 1868,

Ferguson, A. M. and Ferguson, J. All About Gold, Gems and Pearls in Ceylon and South India. Colombo A. M. \& J. Ferguson, 1881.

Foster, Robert J. "Your Money, Our Money and the Government's Money: Finance and Fetishism in Melanesia." In Patricia Spyer (ed.), Border Fetishisms: Material Objects in Unstable Spaces, 60-96. London: Routledge, 1998.

Foster, Robert J. Foster, Materializing the Nation: Commodities, Consumption, and Media in Papua New Guinea. Bloomington, IN: Indiana University Press, 2002.

Foucault, Michael. "Of Other Spaces." Diacritics 16, no. 1 (1986): 22-27.

Frow, John. "A Pebble, a Camera, a Man who turns into a Telegraph Pole." Critical Inquiry 28, no. 1 (Autumn 2001): 270-85. 
Govindan, V. "Fishery Statistics and Information: West and East." Madras Fishery Bulletin 9 (1916).

Guichard, Charlotte. "The Shell in the 18th century: A border object?", Techniques and Culture, 59 no.2 (2012): 150-163.

Gujral, Diva "Pictures in the Water: On Time and Memory in Lionel Wendt's Ceylon." Unpublished MA dissertation, University College London (2016).

Gupta, Radhika. "Changing Courses: A Comparative Analysis of Ethnographies of Maritime Communities in South Asia." Maritime Studies 2, no. 2 (2003): 21-88. Hardin, Garrett "The Tragedy of the Commons." Science 162, no. 3859 (1968): 1243-48.

von Helmholtz, Hermann. On the Sensations of Tone as a Physiological Basis for the Theory of Music. London: Longmans Green, 1862.

Helmreich, Stefan. "Sea Shell Sound: Echoing Ocean, Vibrating Air, Brute Blood." Cabinet I 48 (Winter 2012-13), n.p.

Helmreich, Stefan "Being the Wave: Bodies and Breakers at the Seaside." Cabinet 56 (Winter 2014-15), n.p.

Helmreich, Stefan. "Nature/Culture/Seawater." American Anthropologist 113, no. 1 (2011): 132-44.

Hornell, James. "The Indian Pearl Fisheries of the Gulf of Manaar and Palk Bay." Madras Fisheries Bulletin XVI, 1-188. Madras: Madras Government Press, 1930, 1-45.

Hornell, James, "The Utilization of Coral and Shells for Lime Building in the Madras Presidency." Madras Fisheries Bulletin 8 (1914-15): 12-21.

Jain, Kajri. Gods in the Bazaar: The Economies of Indian Calendar Art. Durham, NC: Duke University Press, 2007.

Juroda, Rajit (ed.). The Gaze of Modernity: Photographs by Lionel Wendt. Fukoka: Fukoka Asian Art Museum, 2003.

Kolisyk, May Helen. "Surrealism, Surrepetition: Artaud's Doubles.” October 64 (Spring 1993): 78-90.

Kunz, George Frederick and Stevenson, Charles Hugh. The Book of the Pearl: Its History, Art, Science, and Industry. London: Macmillan \& co., 1908; New York: David \& Charles, 2002.

Leslie, Esther. Synthetic Worlds: Nature, Art and the Chemical Industry. London: Reaktion, 2005.

Lionel Wendt Centre. Lionel Wendt: A Centennial Tribute. Colombo: Lionel Wendt Memorial Fund, 2000.

Lloyd, William Forster. Two Lectures on the Checks to Population. Oxford: Oxford University Press, 1833.

McCoy, Bonnie J. and Acheson, James M. (eds). The Question of the Commons: The Culture and Ecology of Communal Resources. Tucson, AZ: University of Arizona Press, 1987.

Malinowski, Branislaw. A Diary in the Strict Sense of the Term. London: Routledge and Kegan Paul, 1967.

Neruda, Pablo. Piedras del Cielo. London: Routledge, 1970.

Neruda, Pablo. Confieso que he vivido: Memoirs, trans. Hardie St Martin. London: Condor Souvenir Press Ltd, 1976.

Novillo-Corrolan, Patricia. "Pablo Neruda's Transnational Modernist Networks: Colombo-Madrid-London-Buenos Aires." Modernist Cultures 12, no. 2 (2017): 198-225.

Oldenberg, Veena. The Making of Colonial Lucknow, 1856-1877. Cambridge: Cambridge University Press, 1984.

Pálsson, Gísli. "The Birth of the Aquarium: The Political Ecology of Icelandic Fishing." In Tim Gray (ed.), The Politics of Fishing. London: Macmillan, 1998.

Percival, Robert. An Account of the Island of Ceylon: Containing its History, Geography, Natural History, with the Manners and Customs of its Various Inhabitants. London: C. and R. Baldwin, 1805.

Pinney, Christopher. "The Parallel Histories of Anthropology and History." In Elizabeth Edwards (ed.), Anthropology and Photography, 1860-1920, 74-95. New Haven, CT: Yale University Press, 1992.

Pinney, Christopher. Camera Indica: The Social Life of Indian Photographs. London: Reaktion, 1997.

Pinney, Christopher. The Coming of Photography in India. London: British Library, 2008.

Pinney, Christopher. Photography and Anthropology. London: Reaktion, 2011.

Power, E. R. “The Pearl Fishers of Ceylon.” Friendship's Offering. London: Smith, Elder and Co., 1837.

Ray, Rajat Kanta. "Asian Capital in the Age of European Domination: The Rise of the Bazaar, 1800-1914." Modern Asian Studies 29, no. 3 (1995): 449-554.

Ryder, Robert. "Walter Benjamin's Shell Shock: Sounding the Acoustical Unconscious." New Review of Film and Television Studies 5, no. 2 (12 July 2007): 135-55.

Sconce, Jeffrey. Haunted Media: Electronic Presence from Telegraphy to Television. Durham, NC: Duke University Press, 2000.

Sen, Sudipta. Empire of Free Trade: The East India Company and the Making of The Colonial Market Place. Philadelphia, PN: University of Pennsylvania Press, 2008.

Shanay, Jhaveri. Jhaveri Contemporary_In Dialogue_Amrita Sher Gill and Lionel Wendt. Mumbai: Jhaveri Contemporary, 2014.

Shklovsky, Viktor. “Art as Technique." (1917) In Literary Theory: An Anthology, 1-14. Maldon MA, Blackwell, 2004.

Silverman, Kaja. The Miracle of Analogy, or the History of Photography, Part One. Stanford, CA: Stanford University Press, 2015.

Spyer, Patricia (ed.). Border Fetishisms: Material Objects in Unstable Spaces. London: Routledge, 1998.

Spyer, Patricia. The Memory of Trade: Modernity's Entanglements on an Eastern Indonesian Island. Durham, NC: Duke University Press, 2000. 
Stambler, Benita. "Maintaining the Photographic Legacy of Ceylon." Archives 4, no. 1 (Fall 2013), n.p.

Stambler, Benita. "A Guide to Locating Photographs of Colonial Ceylon," November 2014, prepared for the American Institute for Sri Lankan Studies, http://www.aisls.org.

Steams, Robert E. C. "Ethno-Conchology: A Study of Primitive Money." Annual Report of the Board of Regents of the Smithsonian Institution (1887) Part 2: 45-65.

Stueart, James. An Account of the Pearl Fisheries of Ceylon with an Appendix. Colombo: Government Press, 1843.

Taussig, Michael. The Devil and Commodity Fetishism in South America. Chapel Hill, NC: University of North Carolina Press, 1980.

Taussig, Michael. My Cocaine Museum. Chicago, IL: Chicago University Press, 2004.

Taussig, Michael. I Swear I Saw This: Drawings in Fieldwork Notebooks, Namely My Own. Chicago, IL: Chicago University Press, 2011.

Taussig, Michael. "Fieldwork Notebooks: Feld-forschungs-notizbücher.” dOCUMENTA 13. Kassel: Hatje Cantz Verlag, 2012.

Taws, Richard. "Telegraphic Images in Post-Revolutionary France." Art History 39, no. 2 (2016): 400-21.

Thompson, Krista. An Eye for the Tropics: Tourism, Photography and Framing the Caribbean Picturesque. Durham, NC: Duke University Press, 2006.

Thornley, Bernard A. with Van Geyzel, L.C. Lionel Wendt's Ceylon. London: Lincolns-Prager, 1950.

Thurston, Edgar. Notes on the Pearl and Chank Fisheries and Marine Fauna of the Gulf of Manaar. Madras: Madras Government Museum, 1912.

Thurston, Edgar. Omens and Superstitions of Southern India. Madras: Government Press, 1912.

Townley Scott, Winfield. “Blood and Seashell.” Poetry 50, no. 4 (July 1937): 34-78.

Vink, Markus. Encounters on the Opposite Coast: The Dutch East India Company and the Nayaka State of Madurai in the 17th Century. Leiden: Brill, 2015.

Wagner, Roy. Lethal Speech: Daribi Speech as Symbolic Obviation. Ithaca, NY: Cornell University Press, 1984.

Warnapala, Kanchaneskes. "Caricaturing Colonial Rule in Sri Lanka: An analysis of Muniandi, The Ceylon Punch." Early Popular Visual Culture 10, no. 3 (2012): 3-56.

Warnapala, Kanchaneskes. "The Portraits of the Colonial Artist in Sri Lanka." Internations 14 (2012): 54-87.

Wickramasinghe, Nira. Metallic Modern: Everyday Machines in Colonial Sri Lanka. New York: Berghahn Books, 2006.

Williams, Charles. Silver Shell, or Adventures of an Oyster. London: Peter \& Galpin, 1867.

Wright, Arnold (ed.) Twentieth-Century Impressions of Ceylon, its History, People, Commerce, Industries and Resources. London: Lloyd's Greater British Publishing Company, 1907.

Yang, Anand. Bazaar India: Markets, Society and the Colonial State in Bihar. Berkeley, CA: University of California Press, 1998. Young, Michael W. Malinowski's Kiriwina: Fieldwork photography, 1915-1918. Chicago, IL: Chicago University Press, 1998. 


\section{Licensing}

The Publishers of British Art Studies are committed to supporting scholarship on British art and architecture of all periods. This publication is made available free of charge at https://www.britishartstudies.ac.uk. We ask users to identify the use of materials made available through this website and to provide an appropriate credit to the to the author and the publication, so that others may find and use our resources.

Except where otherwise noted, this work is licensed under a Creative Commons Attribution-NonCommercial 2.0 UK: England \& Wales Licence (CC BY-NC 2.0 UK). To view a copy of this license, visit https://creativecommons.org/licenses/by-nc/2.0/uk/ or send a letter to Creative Commons, PO Box 1866, Mountain View, CA 94042, USA.

The Publishers fully support the protection of intellectual property and are committed to complying with, and strictly adhering to, all applicable copyright law. In many cases, copyright or other proprietary rights may be held by individuals or entities other than, or in addition to, the Publishers. If a work or a photographic image is still protected by copyright, you must cite the relevant copyright information when using the image and comply with all other terms or restrictions that may be applicable to that material.

In some cases, exceptions to copyright that permit limited use of protected works without the permission of the copyright owner may have be applied. We are confident that we have carried out due diligence in our use of copyrighted material as required, but we apologise for any inadvertent infringement of rights.

Digital copies of resources are made accessible for research for one of the following reasons:

- they are in the public domain;

- the rights are owned by the Publishers;

- we make them accessible under an exception or limitation to UK copyright law, as outlined in the Copyright, Designs and Patents Act 1988 (as amended);

- we have permission to make them accessible;

- or, there are no known restrictions on use.

If you believe that we have made a mistake and wish for your material to be removed from our site, please contact us at copyright@paul-mellon-centre.ac.uk.

Please include the following information with your request:

- Name and contact information, including email address and phone number.

- Identification of the resource for consideration of removal. Providing URLs in your communication will help us locate content quickly.

- The reason for the request.

The Publishers respond promptly, normally within 21 business days. We may remove the resource from our site while we assess the validity of the request. Upon completion of the assessment, we will take appropriate action and communicate that action to you. 